University of Wyoming College of Law

Law Archive of Wyoming Scholarship

$11-30-2015$

\title{
Livestock Production, Climate Change, and Human Health: Closing the Awareness Gap
}

Debra L. L. Donahue

University of Wyoming College of Law, ddonahue@uwyo.edu

Follow this and additional works at: https://scholarship.law.uwyo.edu/faculty_articles

\section{Recommended Citation}

Donahue, Debra L. L., "Livestock Production, Climate Change, and Human Health: Closing the Awareness Gap" (2015). Faculty Articles. 10.

https://scholarship.law.uwyo.edu/faculty_articles/10

This Article is brought to you for free and open access by the UW College of Law Faculty Scholarship at Law Archive of Wyoming Scholarship. It has been accepted for inclusion in Faculty Articles by an authorized administrator of Law Archive of Wyoming Scholarship. 


\section{A R T I C L E S}

\section{Livestock Production, Climate Change, and Human Health: Closing the Awareness Gap}

\section{by Debra L. Donahue}

Debra L. Donahue is a Professor of Law at the University of Wyoming College of Law.

\section{Summary}

Livestock should be removed from public lands for myriad reasons. Eliminating what is now extensive grazing by ruminants would cut methane emissions, with attendant benefits for climate mitigation. Removing livestock from public lands also mirrors federal nutrition policy, particularly the recommendation to eat less red meat. Much of the degraded environmental conditions on public lands and waters caused by ruminant grazing would end, thereby enabling improvement or even recovery. Finally, undertaking this policy shift would make fiscal sense by saving taxpayer dollars.

\section{Introduction}

The approximate magnitude of greenhouse gas (GHG) emissions attributable to livestock production has been known since publication of the U.N. Food and Agriculture Organization's (FAO) seminal 2006 report, Livestock's Long Shadow. ${ }^{1}$ The FAO estimated that livestock production was responsible for $18 \%$ of global GHG emissions in carbon dioxide equivalent $\left(\mathrm{CO}_{2}\right.$-eq), including $35-40 \%$ of all anthropogenic emissions of methane $\left(\mathrm{CH}_{4}\right)$, and $65 \%$ of nitrous oxide $\left(\mathrm{N}_{2} \mathrm{O}\right){ }^{2}$ Livestock's total contribution to climate warming thus exceeded that of the global transportation sector. ${ }^{3}$ The FAO "deliberately" chose the title of its report "so as to help raise the attention of both the technical and the general public to the very substantial contribution of animal agriculture to climate change and air pollution, to land, soil and water degradation and to the reduction of biodiversity."'4

Although estimates of GHG emissions attributable to livestock vary somewhat, the "estimates of international scientific organizations, such as the International Governmental Panel on Climate Change (IPCC) and the FAO, are in close agreement."' According to the FAO's most

Author's Note: My thanks to the College of Law Dean's Discretionary Fund for support of this Article.

1. Henning Steinfeld et al., Food \& Agric. Org. of the United Nations (FAO), Livestock's Long Shadow: Environmental Issues and Options (2006).

2. Id. at 112 , tbl. 3-12 at $113,114,272$. The FAO considered carbon emissions from livestock respiration, burning fossil fuels to produce fertilizer for animal feed, methane release from breakdown of fertilizers and manure, land use changes for grazing and feed production, land degradation, fossil fuel use during feed and animal production, and fossil fuel use in production and transport of processed and refrigerated animal products. See id. at 85-86, tbl. 3-12 at 113. "The bulk of [livestock-related] GHG emissions originate from four main categories of processes: enteric fermentation, manure management, feed production and energy consumption." Pierre J. Gerber et al., Food \& Agric. Org. of the United Nations, Tackling Climate Change Through Livestock: A Global Assessment of Emissions and Mitigation Opportunities 20 (2013). See also William J. Ripple et al., Ruminants, Climate Change and Climate Policy, 4 Nature Climate Change 2 (2014), doi:10.1038/nclimate2081 (reporting that about $40 \%$ of emissions are methane from enteric fermentation, manure, and rice feed; the rest are about equal amounts of $\mathrm{CO}_{2}$ from land use change and fossil fuel use, and $\mathrm{N}_{2} \mathrm{O}$ from fertilizer applied to feed-crops fields and manure).

3. STeinfeld ET Al., supra note 1, at 272. Indeed, global GHG emissions from livestock production exceeded the entire 2011 GHG emissions of the United States. See Rob Bailey et al., Livestock: Climate Change's Forgotten Sector: Global Public Opinion on Meat and Dairy Consumption 4 (Chatham House: Royal Inst. of Int'l Affs., Research Paper, 2014) (citing World Res. Inst. Climate Analysis Indicators Tool, available at http://cait2.wri.org).

4. Steinfeld et AL., supra note 1, at iii.

5. See Mario Herrero et al., Livestock and Greenhouse Gas Emissions: The Importance of Getting the Numbers Right, 166-67 Animal FeEd. SCI. \& TeCh. 779, 779 (2011) (noting that estimates range from 8\% to 51\%). They explained that the variation "mainly aris[es] on how GHG emissions are allocated to land use and land use change. Other estimates involve major deviations from international protocols, such as estimated global warming potential of $\mathrm{CH}_{4}$ [methane] or including respired $\mathrm{CO}_{2}$ in GHG emissions." Id. (citing Robert Goodland \& Jeff Anhang, Worldwatch Inst., Livestock and 
recent calculations, "GHG emissions from livestock supply chains . . . represent 14.5 percent of all human-induced $\left[\mathrm{CO}_{2}\right.$-eq] emissions." ${ }^{\prime}$ Most scientists agree that the global share of total GHG emissions from livestock production is in the range of $14-18 \% .^{7}$ Notably, livestock production is the largest anthropogenic source of two important non$\mathrm{CO}_{2}$ gases, $\mathrm{CH}_{4}$ and $\mathrm{N}_{2} \mathrm{O}$. Each of these is a potent $\mathrm{GHG} .{ }^{8}$ "Cattle are the main contributor to the sector's [GHG] emissions." In the United States, livestock is the number one source of methane. ${ }^{10}$

According to the FAO, "[b]etter knowledge and growing willingness to act create a momentum to tackle climate change with livestock." 11 To date, however, climate control efforts have largely ignored animal agriculture. Nearly all efforts have focused on $\mathrm{CO}_{2}$ emissions from energy and transportation, neglecting agriculture generally and livestock production in particular. ${ }^{12}$ "Of the 40 developed countries listed under Annex I of the UNFCCC [U.N. Framework Convention on Climate Change], only Bulgaria

Climate Change. What If the Key Actors in Climate Change Were Pigs, Chickens and Cows? 10 (2009) (estimating GHG emissions at $51 \%)$ ). According to Mario Herrero et al., the FAO used "well documented and rigorous life cycle analyses." Herrero et al., supra, at 780

6. See Gerber et al., supra note 2, at 15.

7. See, e.g., Ripple et al., supra note 2, at 2; Philip K. Thornton \& Mario Herrero, The Inter-Linkages Between Rapid Growth in Livestock Production, Climate Change, and the Impacts on Water Resources, Land Use, and Deforestation 53 tbl. 9 (World Bank Pol'y Res. Working Paper No. 5178, 2010); Philip K. Thornton, Livestock Production: Recent Trends, Future Prospects, 365 PHIL. Trans. R. Soc. 2853, 2861 (2010); Anthony J. McMichael et al., Food. Livestock Production, Energy, Climate Change, and Health, 370 LANCET 1253 (2007). The U.S. Environmental Protection Agency (EPA) estimates that all of "agriculture accounted for close to 10 percent of the United States' total emissions in 2012," but the "amount of methane and nitrous oxide released by livestock manure management systems has gone up 55 percent" since 1990. See Nina Heikkinen, In First-Ever Environmental Review, Federal Advisers Call for Less Red Meat in National Diet, GreenWIre, Mar. 25, 2015.

8. See, e.g., FAO, The Role of Livestock in Climate Change (2015), http://www. fao.org/agriculture/lead/themes0/climate/en/; Gerber ET AL., supra note 2, at 15 .

9. Gerber ET AL., supra note 2, at 15.

10. See U.S. EPA, Overview of Greenhouse Gases, http://www3.epa.gov/climatechange/ghgemissions/gases/ch4.html (last visited Sept. 18, 20015). But see Scot M. Miller et al., Anthropogenic Emissions of Methane in the United States, 110 Procs. Nat'L Acad. Sci. 20018, 20020, 20022 (2013) (reporting that EPA has underestimated methane emissions, including emissions from both animal agriculture and oil and gas development, by a factor of approximately 1.5). See also Ripple et al., supra note 2; National Aeronautics \& Space Admin. (NASA), U.S. Methane "Hot Spot" Bigger Than Expected, http://science.nasa.gov/science-news/science-at-nasa/2014/09oct_ methanehotspot/; Beth Gardiner, How Growth in Dairy Is Affecting the Environment, N.Y. Times, May 1, 2015, available at http://www.nytimes. com/2015/05/04/business/energy-environment/how-growth-in-dairy-is-affecting-the-environment.html?smprod=nytcore-ipad\&smid=nytcore-ipadshare\&_r=0; Miller, supra, at 20020-21 (suggesting that ruminants and agriculture are partly responsible for high methane levels over California).

11. GeRBer ET AL., supra note 2, at x.

12. See, e.g., Bailey et al., supra note 3 , at 12 (noting the worldwide efforts to reduce energy demand, but the total absence of "efforts to moderate meat and dairy consumption"); Stefan Wirsenius et al., Greenhouse Gas Taxes on Animal Food Products: Rationale, Tax Scheme and Climate Mitigation Effects, 108 Climatic Change 159 (2011). and France have established a quantitative reduction target for livestock-related emissions." ${ }^{13}$ Negotiations within the UNFCCC framework on agriculture "have been disproportionately slow."14 "Livestock's long shadow" has been conspicuously absent from most policy discussions.

U.S. policymakers in particular seem to be in denial concerning both the threat posed by GHG emissions from the livestock sector, and the potential that control efforts directed specifically at these emissions hold for climate mitigation. ${ }^{15}$ Compounding the problem, recent research indicates that the U.S. Environmental Protection Agency (EPA) has drastically underestimated livestock-related methane emissions. ${ }^{16}$

Increasing numbers of scientists are warning that restricting the global temperature increase to $2^{\circ} \mathrm{Cel}-$ sius (C) above pre-industrial levels (the stated objective of the international community ${ }^{17}$ ) will not be possible without significant near-term reduction of emissions, particularly methane, from livestock production. ${ }^{18}$ The greatest methane reductions can be accomplished by cutting livestock, and primarily ruminant meat, production. This is a formidable challenge, given the growing human population and rising global demand

13. Bailey et al., supra note 3 , at 7-8.

14. See Ripple et al., supra note 2, at 4 (referring to the category of land use, land use change, and forestry and reducing emission from deforestation and forest degradation, and citing the UNFCC, http://unfccc.int); $c f$. GERBER ET AL., supra note 2, at 91-92. The IPCC now refers to Agriculture, Forestry, and Other Land Use, or AFOlU. See Climate Change 2014: Mitigation of Climate Change, Working Group III Contribution to the Fifth Assessment Report of the Intergovernmental Panel on Climate Change 811 (Ottmar Edenhofer et al. eds., 2014) [hereinafter IPCC Working Grp. III].

15. See, e.g., D. Bruce Myers Jr., Getting Serious About Greenhouse Gas Emissions From U.S. Livestock Production, 19 No. 3 ABA Agric. Мgmt. Сомm. Newsl. 5, 39 (Apr. 2015) (noting that EPA Administrator Gina McCarthy, in response to questioning at a U.S. House of Representatives Science Committee hearing in November 2013, denied that the Agency was considering regulating methane from cows). But see U.S. EPA, Greenhouse Gas MitigAtion Potential in U.S. Forestry and Agriculture, EPA 430-R-05-006, at 7-1 (2005) ("Changes in land-use and management practices as a result of GHG mitigation actions can produce non-GHG environmental co-effects," including benefits to "water quality, air quality, soil quality, and biodiversity.").

16. See Miller et al., supra note 10, at 20020, 20022 (reporting that livestock operations across the United States have emissions approximately twice that of recent inventories). These workers also reported that EPA had underestimated methane emissions from oil and gas activities in the south-central states by an even larger factor. Id. (citing U.S. EPA, InVENTORY OF U.S. Greenhouse Gas Emissions and Sinks: 1990-2011, Technical Report EPA 430-R-13-001 (2013)).

17. See, e.g., UNFCCC, Report of the Conference of the Parties on its 15 th session, held in Copenhagen from Dec. 7-19, 2009 (Mar. 30, 2010), available at http://unfccc.int/resource/docs/2009/cop15/eng/11a01.pdf. To limit the global mean temperature increase to less than $2^{\circ} \mathrm{C}$, GHG concentrations must be stabilized below 450 parts per million $\mathrm{CO}_{2}$-eq. See Elke Stehfest et al., Climate Benefits of Changing Diet, 95 Climatic CHange 83, 84 (2009). To achieve this, GHG emissions in 2050 will "need to be $40-80 \%$ lower than in 2000." Id.

18. See, e.g., Bailey et al., supra note 3, at 1, 4, 22; Ripple et al., supra note 2, at 4 . 
for meat and dairy products. ${ }^{19}$ It will not be met without significant dietary changes.

This Article begins by explaining in Part II.A. why many scientists believe that a significant reduction in current levels of meat consumption in developed nations is needed to avoid exceeding the $2^{\circ} \mathrm{C}$ temperature threshold. It then offers in Part II.B. a brief sketch of the myriad adverse environmental impacts of livestock production and the health consequences of consuming too much meat, especially beef. Next, the Article considers in Part II.C. the mismatch between U.S. dietary guidance and agricultural policy, and how that mismatch undermines the nation's ability to address both the environmental issues and health problems inherent in livestock production. In Part II.D., the Article contends that the United States should take the lead in pursuing agricultural policy reforms aimed at reducing livestock-related GHG emissions, and that its approach should emphasize the co-benefits for health and the environment achievable by reducing meat (especially ruminant meat) production and consumption. Focusing on co-benefits could help overcome concerns about intrusion or interference by government in matters of personal choice. Finally, the Article offers livestock grazing on federal public lands as an example of the pressing need to reform meat production policies, and argues that ending this practice would be a sensible and meaningful first step.

\section{Livestock Production and the Environment}

\section{A. Significant Reduction in Livestock Production- Related GHG Emissions Is Essential}

Containing the global temperature increase within $2^{\circ} \mathrm{C}$ will not forestall adverse climate-related impacts— they are already occurring — but the general hope has been that holding to that limit would lessen the risk of crossing irreversible tipping points. ${ }^{20}$ Triggering climate feedbacks, where rising temperatures trigger even greater releases of GHGs that in turn increase temperatures, is one possible outcome of exceeding tipping points. For example, one scientist predicted that it "will be difficult-perhaps impossible-to avoid large methane releases in the East Siberian Sea without major reductions in global emissions of $\mathrm{CO}_{2}{ }^{.21}$ The release

19. See, e.g., Thornton \& Herrero, supra note 7, at 9-13; see also generally McMichael et al., supra note 7, at 1257.

20. See, e.g., Ripple et al., supra note 2, at 4; Ian Allison et al., Univ. of New South Wales Climate Change Research Centre, Copenhagen Diagnosis 2009: Updating the World on the Latest Climate Science 42 (noting that " $1{ }^{\circ} \mathrm{C}$ global warming (above 1980-1999) carries moderately significant risks of passing large-scale tipping points, and $3^{\circ} \mathrm{C}$ global warming would give substantial or severe risks"); cf. Bojana Bajželj et al., Importance of Food-Demand Management for Climate Mitigation, 4 Nature Climate Change 924, 928 (2014) ("Reducing emissions from agriculture is essential to reduce the risks of dangerous climate change.").

21. Gail Whiteman et al., Vast Costs of Arctic Change, 499 Nature 401, 403 (2013), doi:10.1038/499401a. But see Timothy M. Lenton, Arctic Climate Tipping Points, 41 AMBIO 10, 19 (2012) ("Whether a tipping point exists is unclear, and beyond 2060 it should become impossible thanks to reductions in ozone depleting gases."). of that methane "will bring forward by $15-35$ years the average date at which the global mean temperature rise exceeds $2^{\circ} \mathrm{C}$ above pre-industrial levels." ${ }^{22}$ The needed reductions are not occurring under current mitigation policies. According to the U.N. Environment Programme (UNEP), "current country pledges to reduce GHG emissions will deliver no more than one-third of what is needed by 2020 to avoid a $2{ }^{\circ} \mathrm{C}$ rise in global temperature. ${ }^{\prime 23}$ Authors of a recent article in Science assert that current policy measures "will allow a long-term increase of $3.6^{\circ} \mathrm{C}$," or nearly twice the target. ${ }^{24}$ Others warn that overall, business-as-usual agriculturerelated emissions alone will "almost reach the full $2^{\circ} \mathrm{C}$ target emissions allowance in 2050." ${ }^{25}$ Furthermore, they caution, "even with ambitious supply-side mitigation in the agriculture sector, without radical shifts in consumption of meat and dairy products, growth in agricultural emissions will leave insufficient space within a two-degree carbon budget for other sectors." 26

Consensus is growing that "[o]nly with large simultaneous reductions in $\mathrm{CO}_{2}$ and non- $\mathrm{CO}_{2}$ emissions will direct radiative forcing be reduced during this century." ${ }^{27} \mathrm{~A}$ major reason for the growing attention to livestock production is its huge role in global methane emissions. As noted in the introduction, livestock production is the largest source of methane, both globally and in the United States. ${ }^{28}$ Methane is the most abundant non- $\mathrm{CO}_{2}$ GHG and a potent one:

[T] on-for-ton, methane traps 25 times more heat than $\mathrm{CO}_{2}$ over a 100-year period. Measured over 20 years, methane's warming impact is 72 times greater than an equivalent weight of $\mathrm{CO}_{2}$. Because methane survives in the atmosphere for only 8-12 years (compared to more than a century for $\mathrm{CO}_{2}$ ), substantial emissions cuts today will diminish con-

22. Whiteman et al., supra note 21 , at 402 . They note that methane "emerging in a sudden burst could linger for longer in the atmosphere, and trigger more rapid temperature changes than if the gas were released gradually." Id. at 403 .

23. See Gerber et al., supra note 2, at 2 (citing U.N. Environment Programme (UNEP), Emissions Gap Report (2013)); see also id. at 2. "Assuming a maximum GHG emission reduction rate of 5 percent per year," . . . the " $2{ }^{\circ} \mathrm{C}$ target will . . be missed if no action is taken before 2027." Id. (emphasis added). According to the Working Group III Contribution to the Fifth Assessment Report of the IPCC, "mitigating emissions along a pathway that would be cost-effective and consistent with likely avoiding warming of more than 2 degrees implies that nearly all governments promptly engage in international cooperation, adopt stringent national and international emission control policies, and deploy rapidly a wide array of low- and zero-emission technologies." IPCC WORKING GRP. III, supra note 14 , at $113-14$.

24. Jonas Meckling et al., Winning Coalitions for Climate Policy, 349 Science 1170, 1170 (2015).

25. Bajželj et al., supra note 20, at 924 (emphasis added).

26. Bailey et al., supra note 3, at 12 (citing Fredrik Hedenus et al., The Importance of Reduced Meat and Dairy Consumption for Meeting Stringent Climate Change Targets, 124 Climatic Change 79 (2014) and Bajželj et al., supra note 20) (emphasis added)).

27. See Ripple et al., supra note 2, at 2, 3 \& fig. 1 b (based on consideration of four emissions scenarios) (citing Stephen A. Montzka et al., Non-CO Greenhouse Gases and Climate Change, 476 Nature 43 (2011)).

28. See id. at 2, 3, fig. 1c (noting that methane emissions from ruminants exceed those from all other source categories, including the natural gas and oil industry); Miller et al., supra note 10, at 20018 (reporting that EPA estimates the principal sources to be (in order of importance) (i) livestock (enteric fermentation and manure management), (ii) natural gas production and distribution, (iii) landfills, and (iv) coal mining). 
centration levels within one to two decades - a critical time frame for slowing warming especially in the earth's most vulnerable regions, such as the poles. ${ }^{29}$

Within the livestock sector, ruminants, primarily cattle and sheep, are the chief concern. ${ }^{30}$ In fact, "[r] uminant production is the largest source of anthropogenic $\mathrm{CH}_{4}$ [methane] emissions." 31 "Globally, ruminants contribute $11.6 \%$ and cattle $9.4 \%$ of all greenhouse gas emissions from anthropogenic sources." ${ }^{2}$ "The FAO estimates that " 25 million domestic ruminants have been added to the planet each year ( 2 million per month) over the past 50 years," and that the global domestic ruminant population in 2011 was 3.6 billion, including 1.4 billon cattle and 1.1 billion sheep. ${ }^{33}$

For these reasons - the much shorter atmospheric lifetime and the greater warming potential of methane, and the concentration of methane emissions in one category of livestock - methane "holds the potential for more rapid reductions in radiative forcing than would be possible by controlling emissions of $\mathrm{CO}_{2}$ alone." ${ }^{34}$ In other words, reducing livestock, and particularly ruminant, production will achieve climate mitigation benefits sooner, buying time to achieve further cuts in energy, transportation, and manufacturing. Some authorities also believe that "decreases in worldwide ruminant populations could potentially be accomplished quickly and relatively inexpensively." 35

To put the matter another way, if humans ate less meat, fewer livestock would be produced, which would in turn "have significant effects on both climate change and mitigation costs." 36 But although scientists widely agree that "[c]onsumption of meat and dairy produce is a major driver of climate change" (as well as many other environmental problems ${ }^{37}$ ), reducing GHG emissions from livestock production poses unique challenges. For one thing, "Although it is theoretically possible to decarbonize energy supply, such complete reductions are unattainable in the livestock part of the agricultural sector." ${ }^{38}$ Even though many supply-side mitigation options are available, ${ }^{39}$ "a decrease in

29. Ashley Pettus, Clean Air Task Force, Methane: Tapping the Untapped Potential (2009) (emphasis added); see also Gerber et Al., supra note 2, at 106. Livestock production is also a major source of $\mathrm{N}_{2} \mathrm{O}$, which has a global warming potential 298 times that of $\mathrm{CO}_{2}$, and remains in the atmosphere for about 109 years. See id.

30. The primary domestic ruminants in the United States are cattle and sheep; buffalo and goats are important in other parts of the world. Non-ruminant classes of livestock, including pigs and poultry, are termed monogastric. See, e.g., id. (citing FAOSTAT, http://go.nature.com/Z23f7E) (last visited Sept. 26, 2015).

31. Ripple et al., supra note 2, at 2. Other important sources are the fossil fuel industry, landfills, biomass burning, and rice production. Id. These authors separated production of coal from natural gas and oil.

32. Ripple et al., supra note 2 , at 2 .

33. FAOSTAT (FAO 2013), http://go.nature.com/Z23f7E (cited by Ripple et al., supra note 2 , at 2).

34. Ripple et al., supra note 2 , at 2 .

35. Id. (acknowledging that political will is a prerequisite).

36. See Stehfast et al., supra note 17, at 99 (referring to the HealthyDiet variant).

37. See, e.g., Bailey et al., supra note 3, at 2; Brian Machovina et al., Biodiversity Conservation: The Key Is Reducing Meat Consumption, 536 ScI. Total Env'T 419 (2015), available at http://dx.doi.org/10.1016/j.scitotenv.2015.07.022.

38. Bajžel et al., supra note 20, at 928 .

39. See generally Gerber et AL., supra note 2, chs. 5 \& 6 . overall agriculture-related emissions can only be achieved by employing demand-side reductions." ${ }^{\prime 40}$ This is so because emissions will continue to increase, as population and consumption increase, unless demand can be curtailed. ${ }^{41}$ " $[\mathrm{I}[\mathrm{f}$ current dietary trends (increasing global consumption of animal products) were to continue, emissions of $\mathrm{CH}_{4}$ and $\mathrm{N}_{2} \mathrm{O}$ would more than double by 2055 from 1995 levels." ${ }^{\prime 42}$ In fact, the global demand for livestock products is projected to grow by $70 \%$, if not double, by $2050 .{ }^{43}$

The GHG-emissions impacts of various foods can be expressed in terms of their "emissions intensity" or "carbon footprint." ${ }^{\prime 4}$ One study compared and reported the global "[a]verage carbon equivalent footprint of protein-rich solid foods [meat, fish, vegetal meat substitutes, and pulses [such as beans]], per kilogram of product." ${ }^{145}$ The largest carbon footprints were those attributable to ruminants, and the single largest category was "extensive beef," that is, "cattle grazing across large pastoral systems." ${ }^{36}$ Extensive beef generates nearly $2 \frac{1}{2}$ times as much $\mathrm{CO}_{2}$-eq per kilogram $(\mathrm{kg})$ of beef product as do conventional or intensive beef systems, typically involving feedlots. ${ }^{47}$ Furthermore, the GHG footprint of ruminant meat consumption is, "on average, 19-48 times higher than that of high-protein foods obtained from plants." 48 Another study that examined the environmental impacts of each of the five main animal-based categories

40. Bajžel et al., supra note 20, at 928 (emphasis added). While improved yields and food distribution are needed, "improved diets and reductions in food waste are also essential to deliver emissions reductions, and to provide enough food for the global population of 2050." Id.; see also Alexander Popp et al., Food Consumption, Diet Shifts and Associated Non-CO, Greenhouse Gases From Agricultural Production, 20 Global Envtl. Change 451, 459 (2010) ("[T] echnological mitigation options . . . have also the capability of decreasing non- $\mathrm{CO}_{2}$ GHG emissions significantly. However, these ... options are not as effective as changes in food consumption. Highest reduction potentials will be achieved by a combination of both approaches."). Supplyside actions include bioengineering efforts to reduce emissions from enteric fermentation, management of grazing soils, and manure storage.

41. See Bailey et al., supra note 3, at 2 ("Even with ambitious supply-side action to reduce the emissions intensity of livestock production, rising global demand ... means emissions will continue to rise.").

42. Bailey et al., supra note 3, at 6 .

43. See Gerber et AL., supra note 2, at 83 (70\% increase); Mesfin M. Mekonnen \& Arjen Y. Hoekstra, A Global Assessment of the Water Footprint of Farm Animal Products, 15 Ecosystems 401, 413 (2012) (double); Stehfast et al., supra note 17 , at 92 (double). Consumption of animal products including ruminant meat is increasing rapidly in developing countries. See Stehfast et al., supra note 17 , at 100 . The drivers of the increasing demand for livestock products have been identified as growth in population, urbanization, income growth, culture, and potentially ethical issues. See, e.g., Thornton \& Herrero, supra note 7 , at 9-15.

44. "Emissions intensity" is defined as the "emissions per unit of output, expressed in $\mathrm{kg} \mathrm{CO}_{2}$-eq per unit of output (e.g., $\mathrm{kg} \mathrm{CO}$-eq per $\mathrm{kg}$ of egg)." Gerber et AL., supra note 2, at xvix. "Carbon footprint" refers to the "total amount of GHG emissions associated with a product along its supply chain; usually expressed in $\mathrm{kg}$ or $\mathrm{t}$ [tons] of carbon dioxide equivalent $\left(\mathrm{CO}_{2}\right.$-eq) per unit of output." Id. at xviii.

45. See Ripple et al., supra note 2, fig. 2 .

46. See id. at 4 \& fig. 2.

47. See id. fig. 2 .

48. Id. at 3 \& fig. 2 (explaining that the "full life cycle [comparison] includ[ed] both direct and indirect environmental effects from 'farm to fork' for enteric fermentation, manure, feed, fertilizer, processing, transportation and landuse change"); see also Gidon Eshel et al., Land, Irrigation Water, Greenhouse Gas, and Reactive Nitrogen Burdens of Meat, Eggs, and Dairy Production in the United States, 111 Procs. Nat'L Acad. Sci. 11996, 11998 (2014) (comparing the animal food categories to three staple plant foods: potatoes, wheat, and rice). 
in the U.S. diet—dairy, beef, poultry, pork, and eggsproduced similar results. ${ }^{49}$ The researchers concluded that producing one megacalorie of beef generates five or more times the GHG emissions of each of the other categories..$^{50}$ Another peer-reviewed study estimated "that production of livestock in 2050 at levels projected by the [FAO] may increase direct livestock-related [GHG] emissions from meat, milk, and egg production on the order of $39 \%$. . . above reported year 2000 levels." ${ }^{51}$ The researchers estimated-based on a suggestion in a prior study that "per capita GHG emissions must fall below one metric ton per year by 2050 to prevent a potentially dangerously destabilizing increase in mean surface temperatures above $2^{\circ} \mathrm{C}$ "that as of 2000, "the livestock sector alone occupied 52\% of humanity's suggested safe operating space for anthropogenic greenhouse gas emissions." ${ }^{2}$

Plainly, neither the United States nor the earth can continue on this track, yet this is precisely our course.

\section{B. Other Environmental Impacts and Health Consequences}

"There is a rich literature on the expected environmental consequences of increased consumption of animal products . . . ."53 In addition to climate change, these environmental costs, and health concerns related to meat consumption especially in developed nations, comprise substantial additional justifications for reducing livestock production.

\section{Environmental Costs}

The FAO report Livestock's Long Shadow was aptly named. ${ }^{54}$ According to the agency, livestock production is "by far the single largest anthropogenic user of land," "probably the largest sectoral source of water pollution," likely "the leading player in the reduction of biodiversity," and a "major stressor on many ecosystems and the planet as a whole." ${ }^{\prime \prime}$ In the

49. Eshel et al., supra note 48, at 11997.

50. See id. at $3 \&$ fig. 1 (noting that the emissions of the other categories are comparable). Other environmental impacts of livestock production reported by Gidon Eshel et al. are discussed below.

51. Nathan Pelletier et al., Forecasting Potential Global Environmental Costs of Livestock Production 2000-2050, 107 Procs. Nat'L ACaD. ScI. 18371, 18372 (2010). The projected increase in livestock production will occur due to both a larger human population as well as increased incomes, which typically cause diets to shift from mostly grains to more meat, dairy, and eggs. See Emily S. Cassidy et al., Redefining Agricultural Yields: From Tonnes to People Nourished Per Hectare, 8 Envtl. Res. Letters 1 (2013), doi:10.1088/1748-9326/8/3/034015 (further noting the estimate that "approximately $40 \%$ of the world's population will undergo this [dietary shift] by the year 2050 ").

52. Pelletier et al., supra note 51, at 18372 (citing Allison et al., supra note 20). A one-ton per capita GHG emission rate "is $80-95 \%$ below the per-capita emissions in developed nations in 2000." Allison et al., supra note 20, at 9; cf. Eshel et al., supra note 48, at 11998 (reporting U.S. annual per capita GHG emissions attributable to meat-eating at 1.1 tons).

53. Mekonnen \& Hoekstra, supra note 43, at 401.

54. STEINFELD ET AL., supra note 1 , at iii.

55. See id. at xx, xxi, xxii, xxiii; see also generally Eshel et al., supra note 48 (reporting the immense environmental burdens imposed by U.S. livestock production in terms of water, land, GHGs, and reactive nitrogen $(\mathrm{Nr}))$.
FAO's estimation, livestock production is "one of the top two or three most significant contributors to the most significant environmental problems, at every scale from local to global." ${ }^{56}$ Considerable research and analysis conducted since 2006 reinforce these conclusions. ${ }^{57}$ For example, a study published in the Proceedings of the National Academy of Sciences in 2014 concluded that livestock-based food production is the key land user and source of water pollution by nutrient overabundance, it competes with biodiversity, and it promotes species extinctions. ${ }^{58}$ As discussed in the prior section, livestock production is also a powerful driver of climate change. Climate change, in turn, heightens other environmental problems caused by livestock, such as demands for water, water pollution, soil loss, proliferation of invasive plant species, and impacts on biodiversity. ${ }^{59}$

Most environmental impacts can be traced to the demands livestock production exerts on resources. Meat and dairy production has been called a "staggeringly inefficient use of resources." ${ }^{\prime 60}$ In the United States, for example, "[a]bout $37 \%$ of the total land area ... (236 Mha [million hectares, or 580 million acres]) was occupied by grazinglands in $2002 .{ }^{\prime \prime}$ Beef requires about $88 \%$ of all U.S. land allocated to producing animal-based calories. ${ }^{62}$ More than one-half of all plant protein produced in the United States is used to feed animals. ${ }^{63}$ Only $14 \%$ of U.S.-produced protein is used as human food; $80 \%$ is used as animal feed. ${ }^{64}$ If U.S. consumption of grain-fed animal products were cut by $50 \%$, calorie availability would increase by "enough to feed an additional 2 billion people." ${ }^{65}$

The land, water, and energy demands of livestock production derive from the inefficiency of livestock in converting feed calories to food for humans. ${ }^{66} \mathrm{~A}$ landmark

56. STEINFELD ET AL., supra note 1 , at $\mathrm{xx}$.

57. See, e.g., Gerber ET Al., supra note 2; Ripple et al., supra note 2; Pelletier et al., supra note 51; Thornton \& Herrero, supra note 7; Clive A. McAlpine et al., Increasing World Consumption of Beef as a Driver of Regional and Global Change: A Call for Policy Action Based on Evidence From Queensland (Australia), Colombia and Brazil, 19 Global Envtl. Change 21, 22 (2009).

58. Eshel et al., supra note 48, at 11996. Eshel et al. included within the category "livestock" beef and dairy cattle, poultry, pigs, and sheep; meat production includes dairy products and eggs. Fish farming, which also entails environmental risks and costs, was not considered. See id. at 11997.

59. See Robert L. Beschta et al., Adapting to Climate Change on Western Public Lands: Addressing the Ecological Effects of Domestic, Wild, and Feral Ungulates, 51 Envtl. Mgmt. 474 (2012).

60. Bailey et al., supra note 3, at 13 (citing Bajželj et al., supra note 20). The authors noted that beef products contain only $2.6 \%$ of the feed and pasture biomass fed to cattle, reflecting a $97.4 \%$ loss. See id.; see also McMichael et al., supra note 7. Despite increases in efficiency, "the ratio of animal product calories to feed calories is, on average, still only about $10 \%$." Cassidy et al., supra note 51, at 2 .

61. Jack A. Morgan et al., Carbon Sequestration in Agricultural Lands of the United States, 65 J. Soll \& WATER Conservation 6A, 7A (2010), doi:10.2489/ jswc.65.1.6A. The authors included pasture lands and rangelands within "grazinglands." See id. at 11A. Globally, 70\% of all agricultural land is used to raise livestock. STEINFELD ET AL., supra note 1, at xxi (further noting that $30 \%$ of earth's land surface is used to produce livestock).

62. See Eshel et al., supra note 48, at 11998-99.

63. See Cassidy et al., supra note 51, at 4.

64. Id.

65. Id. at 6 (adding a caveat that a "limitation of this study is that it treats plant and animal proteins equally, even though their proteins differ in bioavailability and amino acid content").

66. See Eshel et al., supra note 48, at 11999 ("The broad resource demand ranges ... partly stem from differences in the basic biology-governed ca- 
U.S. study in 2014 apportioned environmental burdens according to the category of animal food. ${ }^{67}$ The researchers determined that beef is "consistently the least resource-efficient" animal product ${ }^{68}$; "beef production demands about 1 order of magnitude more resources than alternative livestock categories." ${ }^{69}$ Specifically, producing beef "requires $28,11,5$, and 6 times more land, irrigation water, GHG, and $\mathrm{Nr}$ [reactive nitrogen], respectively, than the average of the other livestock categories." ${ }^{70}$ Yet, it is the "second most popular animal category in the mean US diet." ${ }^{\prime 1}$ Accordingly, "minimizing beef consumption mitigates the environmental costs of diet most effectively." ${ }^{2}$

Other researchers predicted substantial increases in the environmental impacts of livestock production by 2050 : $39 \%$ greater GHG emissions, $21 \%$ greater appropriation of plant biomass, and 36\% increase in $\mathrm{Nr}$ mobilization. ${ }^{73}$ Their modeling indicated that, "by 2050, the livestock sector alone may either occupy the majority of, or considerably over shoot, current best estimates of humanity's safe operating space" with respect to climate change, $\mathrm{Nr}$ mobilization, and appropriation of plant biomass at planetary scales. ${ }^{74}$ The problems are further amplified because, as food production using current methods increases, the environmental impacts can be expected to increase disproportionately, in part because of diminishing resource supplies and because many current environmental conditions may well be nearing tipping points.

Many research scientists would agree with one study's conclusion that "reining in the global livestock sector should be considered a key leverage point for averting irreversible ecological change and moving humanity toward a safe and sustainable operating space." 75

pacity of different farm animals to convert feed energy into calories consumed by humans.").

67. Id. at 11996. Their results were "obtained by multiplying the values of Fig. $2 E$, recast as annual overall national caloric consumption, by the resource per megacalorie of Fig. 2A-D." Id. at 11998 (fig. 3).

68. Id. at 11998.

69. Id. at 11996 (emphasis added).

70. Id. at 11998. $\mathrm{Nr}$ can cause a range of negative environmental effects and poses risks to human health. For example, biodiversity losses have occurred in natural grasslands and forest areas due to $\mathrm{Nr}$-induced decreases in abundance of $\mathrm{Nr}$-limited tree and grass species and replacement by Nr-loving weed species. And elevated leaching of $\mathrm{Nr}$ to aquatic systems via both groundwater and surface runoff can result in cascading effects. See Impacts of Nr on Aquatic, Atmospheric, and Terrestrial Ecosystems, in U.S. EPA SCI. Advisory Bd., Reactive Nitrogen in the United States: An Analysis of Inputs, Flows, Consequences and Management Options, EPASAB-11-013 (2011).

71. Eshel et al., supra note 48, at 11999.

72. Id. at 11996; compare Wirsenius et al., supra note 12. Stefan Wirsenius et al. studied the GHG mitigation potential achievable by imposing consumption taxes on animal food products. They concluded that "reduced ruminant (cattle and sheep) meat consumption accounts for the greater part of the climate mitigation effects," and thus "a GHG tax on ruminant meat alone would ... lead to a GHG mitigation corresponding to about $80 \%$ of that for the tax scheme considered in this study." Id. at 178.

73. Pelletier et al., supra note 51, at 18372.

74. Id. While acknowledging the "considerable uncertainty" in their modeling, the scientists also point out that the estimates may be conservative. Id. at 18372, 18373. A "safe operating space" for economic activities at a global scale is defined by biophysical limits, or environmental boundary conditions. See id. at 18371 (citing J. Rockstrom et al., A Safe Operating Space for Humanity, 461 NaTURE 471 (2009)).

75. Id. at 18373.

\section{Health Effects}

Although animal foods are good sources of protein, an essential nutrient for humans, it has been said that "high consumption of meat and dairy products in the Western diet has created wide scale nutritional problems rather than solving them." 76 Strong correlations have been identified between "high levels of meat consumption," particularly beef and pork, and several chronic diseases, including obesity, diabetes, some common cancers and heart disease. ${ }^{77}$ In late October 2015, the World Health Organization's (WHO's) International Agency for Research on Cancer concluded, based on more than 800 epidemiological studies, that consumption of processed meat (most of which contains pork or beef) is "carcinogenic to humans" and consumption of red meat is "probably carcinogenic to humans." ${ }^{\prime 8}$ Nutritional guidelines established by governmental authorities and nongovernmental organizations (NGOs) have long recommended a diet higher in plant foods than in meat (as well as lower in refined sugars and other processed foods). ${ }^{79}$ Taking environmental considerations explicitly into account for the first time, in 2015, the federal Dietary Guidelines Advisory Committee (DGAC) declared: "Americans need to eat less red meat, both for their own health and for the health of the planet." ${ }^{\circ 0}$ Americans consume more meat than almost any other nation. Meat consumption in the United States averages 270 pounds per person per year, an amount said to be exceeded only by citizens of Luxembourg; this includes more than

76. See Alejandro D. González et al., Protein Efficiency Per Unit Energy and Per Unit Greenhouse Gas Emissions: Potential Contribution of Diet Choices to Climate Change Mitigation, 36 Food PoL'y 562, 569 (2011) (emphasis added) (citing WHO-FAO, 2003; WCRF, 2009; Harvard, 2010).

77. Ripple et al., supra note 2, at 3 (citing American Dietetic Ass'n, $109 \mathrm{~J}$. Am. Dietetic Ass'n 1266 (2009); G.E. Fraser, 89 (supp.) Am. J. Clin. Nutr. 1607 (2009)). See also Stehfast et al., supra note 17, at 84; Rosemary Green et al., The Potential to Reduce Greenhouse Gas Emissions in the UK Through Healthy and Realistic Dietary Change, 129 Climatic Change 253, 257 (2015); Scientific Report of the 2015 Dietary Guidelines Advisory Committee [hereinafter 2015 DGAC Report], available at www.health.gov/dietaryguidelines/2015-scientific-report/. The 2015 DGAC Report is used by the Departments of Health and Human Services and Agriculture in developing the 2015 edition of Dietary Guidelines for Americans. See 2015 DGAC Report, app. E-6: History of Dietary Guidance Development in the United States and the Dietary Guidelines for Americans 3 (2015), http://health.gov/dietaryguidelines/2015-scientificreport/18-appendix-e6.asp.

78. See Véronique Bouvard et al. (on behalf of Int'l Agency for Research on Cancer Monograph Working Group), Carcinogenicity of Consumption of Red and Processed Meat, Lancet Oncology (Oct. 26, 2015), at http://www. meatpoultry.com/ /media/Files/MP/IARC-summary.ashx.

79. See, e.g., 2015 DGAC REPORT, supra note 77, at 3. See also generally World Health Org. (WHO), Dietary Recommendations/Nutritional Requirements, http://www.who.int/nutrition/topics/nutrecomm/en/; FAO, Food-Based Dietary Guidelines, http://www.fao.org/nutrition/nutrition-education/fooddietary-guidelines/en/.

80. See 2015 DGAC Report, supra note 77, at 7; see also Heikkinen, supra note 7 (describing 2015 DGAC Report); see also Tennille Tracy, Diet Experts Push More Plants, Less Meat in Nod to Environment, Wall St. J., Feb. 20, 2015 ("Americans are eating less meat than they have in the past, but they are still eating too much, according to the panel's experts, and all that meat consumption is having detrimental effects on the environment."), available at http://www.wsj.com/articles/diet-experts-push-more-plants-less-meat-innod-to-environment-1424368897. 
50 pounds of beef, down from a high of about 90 pounds in the early 1970 s. $^{81}$

The evidence examined by the DGAC "identifie[d] that a healthy dietary pattern is higher in vegetables, fruits, whole grains, low- or non-fat dairy, seafood, legumes, and nuts; . . . lower in red and processed meat; and low in sugar-sweetened foods and drinks and refined grains." ${ }^{2}$ In the United States, the diets of a majority of Americans are deficient in one or more of these categories. ${ }^{83}$ The DGAC advised adoption of more "sustainable" diets, that is, diets lower in calories and animal-based foods, with low environmental impacts, which "contribute to food and nutrition security and to healthy life for present and future generations." ${ }^{84}$ According to the DGAC, a variety of dietary patterns are available, all of which "are aligned with lower environmental impacts [i.e., reduced GHG emissions, land use, water use, and energy] and provide options that can be adopted by the U.S. population." ${ }^{85}$ An empirical study in the United Kingdom (U.K.) showed that "a 40\% reduction in [GHG] emissions can be achieved without consuming an entirely vegan diet, due to switching to types of animal products with lower associated emissions, and reducing consumption of other foods such as pasta, pizza and savoury snacks, which have relatively high emissions and

81. See Eliza Barclay, A Nation of Meat Eaters, The SALt, NPR, June 27, 2012 (citing FAO, FAOSTAT online statistical service), http://www.npr.org/ sections/thesalt/2012/06/27/155527365/visualizing-a-nation-of-meateaters; accord Speculative Investment: The Missing Factor in Global Food Price Increases, Global Food Pol., Apr. 14, 2013 (displaying annual per capita meat consumption by country), https://globalfoodpolitics.wordpress. com/2013/04/14/speculative-investment-the-missing-factor-in-globalfood-price-increases/(last visited Oct. 1, 2015). But cf. Janet Larsen, Peak Meat: U.S. Meat Consumption Falling, Earth Pol'y Inst., Mar. 17, 2012 (reporting that meat consumption fell from a high of 184 pounds in 2004 to 171 pounds in 2011, and an estimated 166 pounds in 2012), http:// www.earthpolicy.org/DATA_HIGHLIGHTS/2012/HIGHLIGHTS 25); accord Tamar Haspel, The Decline of the (Red) Meat Industry - in One Chart, Fortune, Oct. 27, 2015, at http://fortune.com/2015/10/27/ red-meat-consumption-decline/.

82. 2015 DGAC REPORT, supra note 77, at 4. A short summary of the DGAC report is available in Joanne Delaney Burke, Dietary Guidelines for Americans: Food Sustainability and Safety, 50 Nutrition Today 174 (2015).

83. See, e.g., 2015 DGAC Report, supra note 77, at 1, 2, passim.

84. Id.; see also FAO, Procs. of Int'l Sci. Symp., Biodiversity and Sustainable Diets, 2010 (2012); cf. Peter Scarborough et al., Dietary Greenhouse Gas Emissions of Meat-Eaters, Fish-Eaters, Vegetarians and Vegans in the UK, 125 Climatic Change 179 (2014), doi:10.1007/s10584-014-1169-1, http://link.springer.com/article/10.1007/s10584-014-1169-1/fulltext.html.

85. See 2015 DGAC Report, supra note 77, at 7, 16 (listing as examples the "healthy US-style pattern, the healthy Mediterranean-style pattern, and the healthy vegetarian pattern"); accord Stehfast et al., supra note 17, at 88-89; cf. Scarborough et al., supra note 84, at 186 (concluding that their empirical research in the U.K. "suggests that advice to reduce the amount of meat and animal-based products in the diet would be consistent with the definition of a 'healthy, sustainable diet"); González et al., supra note 76, at 569 (noting that "protein deficiency is generally due to lack of variety and quantity of food rather than to lack of meat," and that "a diverse and well designed plant-based diet could provide protein at the lowest possible environmental cost"). But see Judith L. Capper, Is the Grass Always Greener? Comparing the Environmental Impact of Conventional, Natural and Grass-Fed Beef Production Systems, 2 Animals 127, 139 (2012), doi:10.3390/ani2020127 (arguing that the beef industry is "well placed to continue its tradition of environmental stewardship, [even though] it faces considerable opposition in terms of consumer perceptions of intensive production systems that may have a negative impact upon social sustainability," and concluding that "all [beef] systems that fulfill the three facets of sustainability [environmental responsibility, economic viability and social acceptability] have a place within the industry"). are also unhealthy." ${ }^{\prime 6}$ Dietary guidelines similar to those issued by the DGAC have been issued by the WHO, ${ }^{87}$ and sustainable diets have been the subject of attention by many other nongovernmental and international organizations ${ }^{88}$ In sum, diets containing reduced amounts of meat and other animal-based foods would improve health, result in lower GHG emissions, and ameliorate other environmental conditions. "National governments that are considering an update of dietary recommendations in order to define a 'healthy, sustainable diet' must incorporate the recommendation to lower the consumption of animalbased products." ${ }^{9}$

\section{Role of U.S. Law in Problems Posed by Livestock Production}

The mismatch between U.S. dietary guidance and environmental regulation on the one hand and agricultural policy on the other hobbles the nation's ability to take action on the environmental issues and health problems inherent in livestock production. ${ }^{90}$ Agriculture has long enjoyed preferential treatment in national and state policy and regulatory arenas. ${ }^{91}$ Federal support is pervasive, and lax or nonexistent environmental regulation allows animal agriculture to impose a wide range of external costs on the public and private landowners. ${ }^{92}$ Examples include

86. Green, supra note 77 , at 262.

87. See WhO, Diet, Nutrition, and the Prevention of Chronic Diseases: Report of a Joint WHO/FAO Expert Consultation (2003).

88. The Health Council of the Netherlands Guidelines recommends reduced consumption of meat. See Scarborough et al., supra note 84, at 188 (noting the Guidelines' "ecological perspective"). The U.N. and the FAO, the Sustainable Development Commission in the United Kingdom (U.K.), the Institute of Medicine (IOM), the Academy of Nutrition and Dietetics, and the National Research Council have all convened working groups and/or commissioned reports. See 2015 DGAC RePorT, supra note 77, at 4; see also Nancy Auestad \& Victor L. Fulgoni III, What Current Literature Tells Us About Sustainable Diets: Emerging Research Linking Dietary Patterns, Environmental Sustainability, and Economics, 6 Advances Nutrition 19 (2015). In addition, see International Standards for Fruit and Vegetables, Organisation for Economic Co-operation (OECD) iLibrary, http://www.oecdilibrary.org/agriculture-and-food/international-standards-for-fruit-andvegetables_19935668 (last visited Oct. 1, 2015).

89. See Scarborough et al., supra note 84 , at 188.

90. The IPCC has identified the elimination of subsidies as a measure that could reduce GHG emissions. See IPCC, Climate Change 2014: Mitigation of Climate Change Summary for Policymakers 31 (2014), available at http://report.mitigation2014.org/spm/ipcc_wg3_ar5_summary-for-policymakers_approved.pdf [hereinafter IPCC SUMMARY FOR POLICYMAKERs].

91. The situation is similar in many industrialized nations. "Livestock subsidies among OECD countries amounted to $\$ 53$ billion in 2013. In the EU [European Union ], cattle subsidies alone exceeded $\$ 731$ million, equivalent to $\$ 190$ per cow." Bailey et al., supra note 3, at 9. The authors opined: "The dearth of policies and funding to tackle livestock emissions stands in marked contrast to the abundance of government support afforded to meat and dairy producers." Id.

92. See generally J.B. Ruhl, Farms, Their Environmental Harms, and Environmental Law, 27 Ecology L.Q. 263 (2000); see also D. Bruce Myers, Livestock's Hoof Print, 31 EnvTL. F. 34, 39 (2014) (The "Waxman-Markey capand-trade climate legislation that passed the [U.S.] House but failed in the Senate in 2010 not only exempted agriculture from emissions reductions, but also provided for agricultural offsets."). Furthermore, all state legislatures have passed some form of a "right-to-farm" law, see, e.g., ElizABETH R. Springsteem, Nat'l Agric. L. Ctr, States' Right-to-Farm Statutes, http://nationalaglawcenter.org/center-publications/; and some states protect agricultural industrial operations from lawsuits by whistleblowers through 
exemption from Clean Water Act $(\mathrm{CWA})^{93}$ regulation of all nonpoint source water pollution caused by extensive grazing and the majority of animal feeding operations (AFOs); limited and uneven EPA regulation of "concentrated" AFOs (CAFOs), which the U.S. Congress intended to be controlled as point source discharges under the CWA; and exemption of AFOs from Clean Air Act $(\mathrm{CAA})^{94}$ controls. $^{95}$ This part highlights four other examples: Farm Bill subsidies to growers of livestock feed, the Beef Checkoff program, EPA's methane reduction efforts, and public-land livestock grazing.

\section{Farm Bill}

Of all federal policies, the Farm Bill's ${ }^{96}$ direct payments programs probably have received the most attention and criticism. ${ }^{97}$ In 2014, Congress substantially revised the

so-called ag-gag laws, see, e.g., ASPCA, Ag-Gag Bills at the State Level, State Anti-Whistleblower Laws as of September 2015, https://www.aspca.org/fightcruelty/advocacy-center/ag-gag-whistleblower-suppression-legislation/aggag-bills-state-level. A federal court recently struck down Idaho's ag-gag law, IDAHO CODE 18-7042, holding that it violated the plaintiffs' right to free speech guaranteed by the First Amendment and the right to equal protection under the Fourteenth Amendment. See Animal Legal Def. Fund v. Otter, No. 1:14-cv-00104-BLW, 45 ELR 20146 (D. Idaho Aug. 3, 2015).

93. 33 U.S.C. $\$ \$ 1251-1387$, ELR STAT. FWPCA $\$ \$ 101-607$.

94. 42 U.S.C. $\$ \$ 7401-7671 q$, ELR Stat. CAA $\$ \$ 101-618$.

95. Relevant background information on these topics can be found in Ruhl, supra note 92; Susan A. Schneider, Food, Farming, and Sustainability: Readings in Agricultural Law 138-64 (2011) Debra L. Donahue, Agricultural and Forestry Impacts, in Adaptation to Climate Change and the Law: U.S. And International Aspects 372-73, 381-83, 398-99 (Michael B. Gerrard \& Katrina F. Kuh, eds., 2012). See also the National Agricultural Law Center website, http://nationalaglawcenter.org/researchby-topic/ (canvassing topics including environmental law, animal feeding operations, animal welfare, checkoff programs, the CWA and the CAA, climate change, commodity programs, conservation programs, food safety, crop and disaster insurance, and pesticides); Doug Gurian-Sherman, Union of Concerned Scientists, CAFOs Uncovered: The Untold Costs of Confined Animal Feeding Operations (2008) (describing feed grain subsidies, and use of federal and state payments under the Environmental Quality Incentives Program (EQIP) to promote manure management, taxpayer-funded costs of cleaning up CAFO water pollution, ammonia and particulate air pollution, reductions in property values, and effects of excess use of antibiotics); Machovina et al., supra note 37, at 427 ("CAFOS are now a major source of atmospheric methane and ammonia releases, nutrient and microbial pollution to aquatic ecosystems, and health problems among local residents." (citations omitted)); Lisa Winebarger, Standing Behind Beastly Emissions: The U.S. Subsidization of Animal Agriculture Violates the United Nations Framework Convention on Climate Change, 27 Am. U. INT'L L. Rev. 991, 995 (2012) (arguing that U.S. subsidies "violate Article 4 of the UNFCCC by promoting greenhouse gas emissions in contravention of its obligation to mitigate emissions").

96. "Farm Bill" is the name by which federal farm support legislation is known. Bills have been passed approximately every five years since 1933. See generally Renée Johnson \& Jim Monke, Cong. Research Serv., RS22131, What Is the Farm Bill? (2014); see also National Agric. L. Ctr, United States Farm Bills., http://nationalaglawcenter.org/farmbills/ (providing links to Farm Bill legislation and other sources).

97. See, e.g., Donahue, supra note 95, at 362, 377-81, 394; Agricultural Subsidies, Opposing Viewpoints Series (Noël Merino ed. 2010); David Dayen, The Farm Bill Still Gives Wads of Cash to Agribusiness, New Republic, Feb. 4, 2014, available at http://www.newrepublic.com/article/116470/ farm-bill-2014-its-even-worse-old-farm-bill; James B. Stewart, Richer Farmers, Bigger Subsidies, N.Y. Times, July 19, 2013, available at http://www. nytimes.com/2013/07/20/business/richer-farmers-bigger-subsidies.html?_ r=0; Environmental Working Grp., The Case for Farm Subsidy Reform, http://www.ewg.org/farming-and-the-environment/the-case-for-farm-subsidy-reform (providing links); Union of Concerned Scientists, Unhealthy Food Policy: How Government Subsidizes the Wrong Foods-and Creates Ob- mechanics, though perhaps not the fiscal impact, of the Farm Bill. ${ }^{98}$ The new legislation substitutes variable payments for the fixed payments that commodity producers had received in the past; it maintains subsidized crop insurance and a marketing assistance loan program. ${ }^{99}$ With one exception, the covered commodities remain the same. ${ }^{100}$ While meat producers do not receive direct support-and did not, under the pre-2014 program-they are eligible for emergency and disaster assistance. ${ }^{101}$ But more importantly, in excess of $84 \%$ of Farm Bill direct payments from 1997 to 2006 went to just five crops, including corn and soybeans produced for livestock feed..$^{102}$

There is wide agreement that Farm Bill subsidies promote unhealthy eating and environmental problems ranging from water pollution to soil erosion to weed proliferation. ${ }^{103}$ While a few sources—notably, the U.S. Department of Agriculture (USDA)—dispute this conclusion, ${ }^{104}$

stacles for Healthy Farms, http://www.ucsusa.org/our-work/food-agriculture/ our-failing-food-system/unhealthy-food-policy.

98. See generally Dennis A. Shields, Cong. Research Serv., R43448, Farm Commodity Provisions in the 2014 Farm Bill (Pub. L. No. 113-79) (2014); U.S. Dep't of Agric., The Farm Bill, http://www.usda.gov/wps/ portal/usda/usdahome?navid=farmbill; see also David Rogers, Payments to Farmers May Exceed Farm Bill's Expectations, Pouitico, Jan. 29, 2015 (reporting that revised Congressional Budget Office $(\mathrm{CBO})$ figures show that "annual payments to farmers could average $\$ 4.8$ billion over the next decade—a nearly 50 percent increase over what CBO had [earlier] predicted," compared to an annual $\$ 4.9$ billion over the prior 20 years); Mark Bittman et al., How A National Food Policy Could Save Millions of American Lives, WAsh. Post, Nov. 7, 2014 (calling the new law "yet another business-asusual farm bill, which continues to encourage the dumping of cheap but unhealthy calories in the supermarket").

99. See SHields, supra note 98, at 1 (explaining that the "most significant policy change for commodity programs ... was the elimination of fixed direct payments and the enhancement of variable payments to farmers and landowners when crop prices or revenue declines").

100. See id. at 2. In response to a trade dispute with Brazil, Congress removed upland cotton, and provided support for it through a new crop insurance policy. Id.

101. See id. at 3, 30-31.

102. See Donahue, supra note 95, at 380; see also National Research Council, Toward Sustainable Agricultural Systems in the 21 st Century 293 (2010); Elanor Starmer \& Timothy A. Wise, Feeding at the Trough: Industrial Livestock Firms Saved \$35 Billion From Low Feed Prices (Global Dev. \& Env't Inst., Tufts Univ., Policy Brief No. 07-03, 2007). During the period 1997-2006, commodity subsidies exceeded $\$ 172$ billion. See Donahue, supra note 95, at 378. Similarly, "about 70 percent of the total premiums charged each year for crop insurance" are for corn, wheat and soybeans. See Rogers, supra note 98.

103. See, e.g., McMichael et al., supra note 7, at 1262; Physicians Comm. for Responsible Medicine, Agriculture and Health Policies in Conflict: How Subsidies Tax Our Health, www.pcrm.org/health/reports/agriculture-andhealth-policies-ag-versus-health; Environmental Working Grp., supra note 97; Donahue, supra note 95, at 378-81, 394; Bittman et al., supra note 98 ("The government subsidizes soda with one hand, while the other writes checks to pay for insulin pumps. This is not policy; this is insanity.").

104. See, e.g., Arthur Allen, U.S. Touts Fruit and Vegetables While Subsidizing Animals That Become Meat, WASH. POst, Oct. 3, 2011 (quoting Robert Post, USDA's deputy director for nutrition policy and promotion, as saying that "basic commodity prices are a tiny percentage of what consumers pay," and that "consumer habits have a much bigger impact than price subsidies"), available at http://www.washingtonpost.com/national/health-science/us-toutsfruit-and-vegetables-while-subsidizing-animals-that-become-meat/2011/08/ 22/gIQATFG5IL_story.html. One study was found that supports Post's conclusion that "farm subsidies have not been a significant cause of obesity trends in the United States." See Julian Alston et al., Farm Subsidies and Obesity in the United States: National Evidence and International Comparisons, 33 Food Pol'y 470, 474 (2008). 
most commentators concur that current agricultural policies are unsustainable. ${ }^{105}$

\section{Beef Checkoff Program}

The Beef Checkoff program is another program plainly at odds with U.S. dietary guidance. ${ }^{106}$ This 30 -year-old program was established by the Beef Promotion and Research Act of $1985,{ }^{107}$ which announced a congressional policy "to strengthen the beef industry's position in the marketplace and to maintain and expand domestic and foreign markets and uses for beef and beef products." 108

The statute directs the Secretary of Agriculture to implement this policy by issuing a Beef Promotion and Research Order ...., and specifies four key terms it must contain, [including imposition of a] \$1-per-head assessment (or 'checkoff') on all sales or importation of cattle and a comparable assessment on imported beef products. [This] assessment is to be used to fund beef-related projects, including promotional campaigns, designed by the Operating Committee and approved by the Secretary. ${ }^{109}$

While the program is funded by cattle producers and beef importers, ${ }^{110}$ not taxpayer dollars, the federal government is inextricably involved. As the U.S. Supreme Court put it: "The message set out in the beef promotions is from beginning to end the message established by the Federal Government." "11 As of 2001, more than $\$ 1$ billion had been collected through the checkoff; "a large fraction of that sum [was] spent on promotional projects authorized by the Beef Act-many using the familiar trademarked slogan 'Beef. It's What's for Dinner."'112 Secretary of Agri-

105. Cf. Donahue, supra note 95 , at 394.

106. Twenty-two checkoff programs are codified in Title 7 of the U.S. Code, covering a wide range of commodities, including pork, cotton, milk, sheep, avocadoes, pecans, soybeans, and watermelons. Each establishes a program designed to promote research, marketing, and sales of the covered commodity, funded by assessments on the producers. The expression "checkoff" is used whether the assessments are mandatory or voluntary. See generally National Agric. Law Ctr., Checkoff Programs (2015).

107. Beef Promotion and Research Act of 1985 (Beef Act), Pub. L. No. 94-294, 99 Stat. 1597, Dec. 23, 1985, 7 U.S.C. $\$ \$ 2901-2911$. The Act defines "promotion" as meaning "any action ... to advance the image and desirability of beef and beef products with the express intent of improving the competitive position and stimulating sales of beef and beef products in the marketplace." See 7 U.S.C. \$290. It defines "industry information" as "information and . . . activities to enhance the image of the cattle industry." Id.

108. 7 U.S.C. $\$ 2901$ (b).

109. Johanns v. Livestock Marketing Ass'n, 544 U.S. 550, 553 (2005) (citations omitted). The petitioners in Johanns challenged the Beef Act and assessment order, alleging that they compelled speech with which the petitioners disagreed. The Court upheld the Act and order, holding that the beef checkoff program is government speech, and that citizens "have no First Amendment right not to fund government speech." Id. at 562.

110. See 7 U.S.C. $\$ \$ 2903$, 2904; see also Johanns, 544 U.S. at 553 (citing 7 U.S.C. $\$ \$ 2901-2911)$.

111. Johanns, 544 U.S. at 560 (emphasis added). The Court stated that the Secretary of Agriculture "exercises final approval authority over every word used in every promotional campaign. All proposed promotional messages are reviewed by Department officials both for substance and for wording .... Officials of the Department also attend and participate in the open meetings at which proposals are developed." Id. at 561 .

112. See id. at 554 (citing Livestock Marketing Ass'n v. U.S. Dep't of Agric., 132 F. Supp. 2d 817, 820 (D.S.D. 2001)). culture Tom Vilsack recently expressed his support for the program, declaring: " $[\mathrm{M}] \mathrm{y}$ goal is that we have [a] healthy beef industry and that producers of all sizes can survive."113

The Beef Checkoff program is problematic in several respects. First, its goal-to increase beef production and consumption-is starkly at odds with both the DGAC's 2015 recommendation discussed above that Americans "eat less red meat," and with USDA's My Plate guidance. My Plate recommends that Americans eat only 2.5 to 6.5 ounces of protein per day (depending on age and sex), and urges them "to make leaner and more varied selections of . . . foods" in the proteins food group. ${ }^{114}$ Furthermore, greater beef consumption exacerbates the environmental problems caused by production of cattle, the ruminant responsible for most of the GHG emissions and other environmental impacts attributable to the livestock sector. And finally, successful marketing of U.S. beef consumption overseas contributes to the troubling trend of rising global meat consumption, while also increasing transportationrelated emissions of $\mathrm{CO}_{2} \cdot{ }^{115}$

\section{EPA's Methane Reduction Efforts}

The Barack Obama Administration recognizes that "[r]educing methane emissions is a powerful way to take action on climate change." 116 Accordingly, the Administration has made reducing methane "a key element of the Climate

113. See Carrie Stadheim, Vilsack Steps Into Checkoff Battle, Tri-State Livesтоск News, Sept. 8, 2014 (quoting Vilsack, who lamented only that "the program is complicated"), http://www.tsln.com/news/12943441-113/ checkoff-beef-group-sombke.

114. USDA, What Foods Are in the Protein Foods Group?, http://www.choosemyplate.gov/protein-foods. Beef, of course, is only one form of available protein. The protein group also includes other "meats, poultry, seafood, beans and peas, eggs, processed soy products, nuts, and seeds." Id. According to USDA's deputy director for nutrition policy and promotion, "My Plate [guidance] doesn't promote any kind of food." See Allen, supra note 104 (quoting Post).

115. The program has also drawn criticism after a USDA-approved industry merger in 1996 put the private trade group National Cattlemen's Beef Association (NCBA) in charge of checkoff funds. See Siddhartha Mahanta, Big Beef: Independent Ranchers and Animal Rights Activists Don't Agree About Much, Except That It's Time to Stop Using Federal Tax Dollars to Support the Meat Lobby, Wash. Monthly, Jan./Feb. 2014 (reporting that "99 percent of all the beef tax dollars collected by the government, some $\$ 45$ million a year," are controlled by the NCBA), available at http://www.washingtonmonthly.com/magazine/january_february_2014/features/big_beef048356. php?page=all, reprinted at http://www.alternet.org/food/ranchers-and-activists-agree-its-time-stop-big-beef-subsidies-0; see also Beef Board, About the Federation of State Beef Councils (2015), http://www.beefboard.org/ about/about-the-federation-of-state-beef-councils. It seems that the NCBA has misappropriated checkoff funds for its own use, perhaps repeatedly. An audit in 2010 led it to return \$216,944 to the government. See Mahanta, supra. The group's lobbying interests increasingly diverge from those of small producers and the public. For example, it has "joined with other trade groups representing meat-packers, including foreign groups, in suing to block the USDA's full implementation of country-of-origin labeling," a policy supported by $87 \%$ of adult Americans and many small producers. See id. (citing a Consumer Federation of America poll in 2013). "The consumer may ask, "Why is my government turning over tax dollars to a trade group that's in court trying to keep me from knowing what I'm eating?"” Id. But the real scandal, this journalist asserts, is "what the law itself allows." See id.

116. White House, Climate Action Plan: Strategy to Reduce Methane Emissions 1 (2014) [hereinafter Strategy], https://www.whitehouse.gov/ blog/2014/03/28/strategy-cut-methane-emissions. 
Action Plan."117 Unfortunately, its methane policies hew to the tradition of giving agriculture a pass. ${ }^{118}$ The White House's 2014 Strategy to Reduce Methane Emissions proposes standards and/or regulations for three of four "targets": methane emissions from landfills, coal mines, and oil and gas activities. ${ }^{119}$ For the fourth target, agriculture, the Strategy "addresses emissions . . . exclusively through voluntary actions." 120 Remarkably, the document omits any mention of enteric fermentation in ruminants, by far the largest anthropogenic source of atmospheric methane, as discussed above. The Strategy also wholly ignores issues related to diet and food consumption. ${ }^{121}$

With respect to agriculture, the White House's Strategy is limited to "outlining voluntary strategies to accelerate adoption of methane digesters" and continuing financial support and technical assistance for "biodigester technology deployment." 122 EPA's support for biogas recovery systems (anaerobic digesters) ${ }^{123}$ may be justifiable. Replacing manure lagoons with anaerobic digesters has the "highest mitigation potential" for treating manure in North American dairy operations. ${ }^{124}$ So far, though, digesters have been adopted by only a small fraction of producers. ${ }^{125}$ Furthermore, they are designed to treat liquid manure, ${ }^{126}$ and thus have little application to most beef cattle operations. ${ }^{127}$ Digesters are also expensive to construct and operate and thus useful only for the largest dairy operations. ${ }^{128}$ For these and other reasons, digesters have many detractors. "The fact that digesters do so little to address the overall emissions of CAFOs," one commentator has written, "makes them a distraction from the bigger environmental and climate change problems stemming from industrial-

117. With respect to agriculture, EPA has dissembled. Its website reports (inaccurately, according to EPA's own data), that "[n]atural gas and petroleum systems are the largest source of $\mathrm{CH}_{4}$ emissions from industry in the United States [29\%]." See U.S. EPA, Overview of Greenhouse Gases: Methane Emissions, http://www3.epa.gov/climatechange/ghgemissions/gases/ch4.html (last visited Sept. 27, 2015). The same graphic, however, shows that this figure is exceeded by the aggregate of two agricultural sources: enteric fermentation (26\%) and manure management (10\%). See id. In its Climate Action Strategy, the Obama Administration does the math, identifying agriculture as the largest source of methane and reporting its contribution at "36 percent." See Strategy, supra note 116, at 4.

118. See Bittman et al., supra note 98 ("When it came to regulating methane, ... the $[\mathrm{EPA}]$ proposed stringent rules for the energy industry - and another voluntary program for agriculture, the single biggest emitter of the gas.").

119. See Strategy, supra note 116, at 2 ("The Administration is pursuing a targeted strategy that builds on progress to date ...."); see also U.S. EPA, RULE and Implementation Information for Standards of Performance fOR Municipal Solid Waste Landfills, http://www3.epa.gov/ttn/atw/ landfill/landflpg.html (last visited Oct.2, 2015); Emily Holden, EPA Proposes Stricter Landfill Methane Regulations, GreenWIre, Aug. 17, 2015.

120. Strategy, supra note 116 , at 6.

121. See Strategy, supra note 116.

122. Id. at 2; id. at 6 ("This strategy addresses emissions from agriculture exclusively through voluntary actions ....."; see also Bittman et al., supra note 98

123. See U.S. EPA, AgSTAR: Biogas Recovery in the Agriculture Sector, http:// www2.epa.gov/agstar; see also Bailey et al., supra note 3 , at $8 \&$ n. 20 .

124. See Gerber et AL., supra note 2, at 77.

125. Id. at 47 .

126. Id. at 78 .

127. See Nicole G. Di Camillo, Methane Digesters and Biogas Recovery: Masking the Environmental Consequences of Industrial Concentrated Livestock Production, 29 UCLA J. Envtl. L. \& Pol'y 365 (2011); cf. Gerber et al., supra note 2 , at $47-48,66$.

128. See generally Di Camillo, supra note 127. scale livestock production." ${ }^{129}$ At least one commentator has argued that subsidizing digester technology may actually lead to greater pollution. ${ }^{130}$

The Strategy's truncated approach to curbing methane emissions severely limits its overall effectiveness. Sadly, it also reinforces the widespread view that agriculture should be immune from environmental controls applicable to every other industry.

\section{Public-Land Livestock Grazing}

A final example (for purposes of this Article) is publicland grazing, which embodies a huge subsidy to a very few ranchers and has profound consequences for publicland ecosystems and the environment in general. ${ }^{131}$ Of the approximately 800,000 livestock operators and cattle producers in the United States, only about 21,000 (2.7\% of the total) benefit from the U.S. Forest Service (USFS) and Bureau of Land Management (BLM) grazing programs. ${ }^{132}$ In 2015, the grazing fee for BLM lands and national forests increased to $\$ 1.69$ per animal unit month (AUM), from the legal minimum of $\$ 1.35$ where it had been since 2007. 133 To reimburse just the "direct appropriation costs for the BLM and USFS programs," however, "the grazing fee would have had to be set at $\$ 10.25$ per AUM based on 2012 figures." 134 Today, the "grazing fee is a smaller fraction $(6.72 \%)$ of the cost to graze on non-irrigated private lands than it was in 1981 (23.79\%)." 135 Federal appropriations for the grazing program have exceeded receipts by at least $\$ 120$ million annually since $2002,{ }^{136}$ but the estimated total direct and indirect costs of public-land grazing are immense, perhaps as much as $\$ 1$ billion per year. ${ }^{137}$

129. See id. at 385.

130. See John Kinsman, Taxpayer Subsidized Manure Digesters Stimulate Factory Farm Pollution, Capital Times, Mar. 14, 2010, http://host.madison.com/ct/ news/opinion/column/article_c83be70c-62aa-59e8-91f7-04db55a0377e. $\mathrm{html}$ (last visited Sept. 28, 2015). (John Kinsman is an organic dairy farmer and president of Family Farm Defenders.)

131. See, e.g., Thomas L. Fleischner, Ecological Costs of Livestock Grazing in Western North America, 8 Conservation Biology 629, 630 (1994); Beschta et al., supra note 59; Jonathan L. Batchelor et al., Restoration of Riparian Areas Following the Removal of Cattle in the Northwestern Great Basin, 55 ENvTL. Мgмt. 930 (2015).

132. See Christine Glaser et al., Center for Biological Diversity, Costs and Consequences: The Real Price of Livestock Grazing on AmeriCA's Public Lands (2015) [hereinafter Costs and Consequences), available at http://www.biologicaldiversity.org/programs/public_lands/grazing/ pdfs/CostsAndConsequences_01-2015.pdf. This report is an update of a 2002 study, Assessing the Full Costs of the Federal Grazing Program, by Chuck Romaniello and Karyn Moskowitz, also prepared for the Center for Biological Diversity [hereinafter Full Costs], available at http://www.biologicaldiversity.org/swcbd/Programs/grazing/Assessing_the_full_cost.pdf.

133. See Costs and Consequences, supra note 132, at 1; see also Carol Hardy Vincent, Cong. Research Serv., RS21232, Grazing Fees: Overview AND Issues (2012), available at https://www.fas.org/sgp/.../RS21232.pd. An AUM is the amount of forage needed to feed a cow and calf, or five sheep, for one month. See, e.g., Costs AND ConseQuences, supra note 132, at 1 .

134. Costs And Consequences, supra note 132, at 19.

135. Id. at 1 .

136. Id.

137. Full Costs, supra note 132, at 1, cited in VINCENT, supra note 133, at 2 \& n.8. 
Livestock grazing is the largest and longest-running extractive use of public lands. Cattle and sheep are permitted to graze on about 230 million acres of public lands$60 \%$ of national forests and $80 \%$ of BLM lands, as well as hundreds of thousands of acres in national parks, monuments, wilderness areas, and wildlife refuges. ${ }^{138}$ This means that in seven western states (Colorado, Idaho, Nevada, New Mexico, Oregon, Utah, and Wyoming), "the majority of [the] land area, and thus the waters that drain those lands, is managed by the federal government for livestock grazing." ${ }^{39}$ Yet, this immense tract of land produces only $2-5 \%$ of total U.S. livestock feed, and the grazing program supports few jobs and generates negligible income. ${ }^{140}$

Livestock grazing exacerbates the effects of climate change on the public lands, hinders the ability of ecosystems to adapt to climate change, and contributes to climate change as a result of methane emissions and reduced potential of soils to sequester carbon. ${ }^{141}$ Moreover, as discussed above, "extensive beef" is the number one emitter of methane, producing nearly $2 \frac{1}{2}$ times as much $\mathrm{CO}_{2}$-eq per $\mathrm{kg}$ of beef product as other production systems. Thus, the methane contribution of public-lands grazing animals must be considered significant. Furthermore, while the forage supplied is relatively small, ${ }^{142}$ livestock's overall environmental impacts are a function of the vast area devoted to the enterprise and to the unique impacts of cattle and sheep-nonnative ungulates - on western ecosystems. ${ }^{143}$

Although no statute mandates that public lands be managed to support domestic livestock, and the issuance

138. See generally Thomas M. Power, Taking Stock of Public Lands Grazing: An Economic Analysis, in Welfare Ranching: The Subsidized Destruction of the American West 263-70 (George Wuerthner \& Mollie Matteson eds., 2002); Debra L. Donahue, The Western Range Revisited: Removing Livestock From Public Lands to Conserve Native BiodiverSITY 252-53 (1999).

139. Bob Hughes, Sacred Cows at the Public Trough Revisited, 39 Fisheries 339 (2014) (emphasis added), doi:10.1080/03632415.2014.932775, http:// dx.doi.org/10.1080/03632415.2014.932775. (Bob Hughes is president of the American Fisheries Society.)

140. Economist Thomas Michael Power reported that federal forage contributed an average of only $0.04 \%$ and $0.07 \%$, respectively, to the income and jobs of the 11 western states. See Power, supra note 138; see also generally Public Land Ranching by the Numbers, in Welfare RanChing, supra note 138, at 5. In 1994, the federal government estimated that eliminating public-land grazing might raise retail beef prices by $1 \%$, though the lost production could be readily offset by an increase in beef production on private lands in other parts of the country. See Donahue, supra note 138, at 252, 259-60 (citing U.S. Dep't of Interior, Rangeland Reform '94, Draft EnVIRONMENTAL IMPACt STATEMENT 41 (1994)).

141. See, e.g., Beschta et al., supra note 59, at 476-81; Ripple et al., supra note 2, at 2,3. Almost nothing is known, however, about the ability of shrublands to sequester carbon. See Jack A. Morgan et al., Carbon Sequestration in Agricultural Lands of the United States, 65 J. Soil \& Water Conservation 6A, 7A (2010), doi:10.2489/jswc.65.1.6A. This is a "critical research need," see $i d$., particularly since shrubs dominate large areas of the public lands.

142. See Beschta et al., supra note 59, at 476 ("Total livestock use of federal lands in eleven contiguous western states today is nearly 9 million animal unit months.").

143. See generally Beschta et al., supra note 59, at 482 :

The combined effects of ungulates... and a changing climate present a pervasive set of stressors on public lands, which are significantly different from those encountered during the evolutionary history of the region's native species. The intersection of these stressors is setting the stage for fundamental and unprecedented changes to forest, arid, and semi-arid landscapes ... and increasing the likelihood of [crossing thresholds to] alternative states. of a permit creates no property interest in the land or the permit, ${ }^{144}$ retiring grazing permits or otherwise bringing an end to grazing has proven to be a nearly intractable problem. ${ }^{145}$ This challenge will be further explored in the next part. As the circumstances described here plainly show, the fact that public-land grazing has been allowed to continue is a stark example of the mismatch between environmental regulation and U.S. agricultural policy.

\section{Taking Action on GHG Emissions From Livestock Production}

Eventually, governments must take action to modify diets so as to reduce GHG emissions from animal agriculture. ${ }^{146}$ The greater the passage of time, however, the greater will be the lost opportunity to make reductions in methane when they could be most efficacious. We may squander the ability to curb overall emissions sufficiently to keep the $2^{\circ} \mathrm{C}$ threshold at bay. This part discusses, first, the need for action by society to address this problem; and, second, why ending public-land grazing would be a rational and meaningful step by the federal government.

\section{Changing Consumer Behavior and Food Policy}

"Despite ample scientific evidence that indicates the ecological problems raised by current meat-consumption patterns and levels, meaningful political attention is conspicuously absent." "147 Governments and most NGOs apparently believe that "trying to reduce consumer demand for meat and dairy products is at best too complex, and at worst risks backlash."148 Some writers have concluded: "Whatever the importance of such policy initiatives in principle, they likely would be regarded as overreaching in practice

144. See Donahue, supra note 138, at 11, 24, 38-39, 64 (discussing nature of grazing privilege, and citing 43 U.S.C. $\$ \$ 315,1751$ ). As I have argued elsewhere, the relevant laws "authorize, if they do not mandate, the cessation of grazing on a sizeable portion of BLM lands." See Debra L. Donahue, Western Grazing: The Capture of Grass, Ground, and Government, 35 EnvTL. L. 721, $763 \&$ n.305 (2005).

145. See, e.g., George C. Coggins et al., Federal Public Land and ResourcES LAW 773-75 (7th ed. 2014) (discussing conservation buyouts and retirement of grazing permits).

146. See, e.g., Mekonnen \& Hoekstra, supra note 43, at 413 ("Managing the demand for animal products by promoting a dietary shift away from a meat-rich diet will be an inevitable component in the environmental policy of governments."); González et al. supra note 76, at 569 ("Environmental limitations appear to inevitably demand more efficient food consumption, which is readily achievable by lowering meat consumption.”); Bailey et al., supra note 3, at 12 ("[D]ietary change is essential if global warming is not to exceed two degrees Celsius . . ...); Stehfest et al., supra note 17.

147. Hans Dagevos \& Jantine Voordouw, Sustainability and Meat Consumption: Is Reduction Realistic?, 9 Sustainability: Sci., Prac. \& Pol'y (Summer 2013), at 60, 66, http://sspp.proquest.com.

148. Bailey et al., supra note 3, at 15 (noting that the perceived obstacles to tackling this problem include "public intolerance of any [government] attempt to interfere in lifestyle decisions," "challeng[ing] the cultural significance of meat," economic and political opposition from the powerful livestock-farm lobby, "public ambivalence regarding climate change," and "[u]ncertainty regarding the efficacy or acceptability of policy interventions"). 
given that a meat-centered paradigm still prevails." ${ }^{149}$ These researchers suggest that an "incremental," more individualized strategy is more appropriate. ${ }^{150}$ Eventually, governance interventions might follow, perhaps adopting an approach of "enabling, encouraging, exemplifying, and engaging." 151

Another, perhaps minority, view exists. A U.K. research team argues: "[B]ehind these concerns lie multiple assumptions and generalizations. The belief that in aggregate they represent an insurmountable challenge is untested, and clear examples of behavioural shifts in populations do exist. In reality there is minimal research on how dietary change might best be effected." 152 In fact, Americans' dietary preferences are neither innate nor immutable. They have changed over time and have been significantly influenced by government food and agriculture policies. ${ }^{153}$

This Article does not weigh in on the debate, however, nor will it attempt to summarize or critique the growing social science research on the subject. Neither undertaking is necessary to the specific proposal made here. While ending public-land grazing requires a change in government policy, it would not entail direct government involvement in meat-eating habits, nor would it (at least not immediately) have noticeable effects on either U.S. livestock production or beef consumption. Moreover, it could be accomplished quickly, a definite advantage " $\mathrm{g}$ ] iven the difficulties in implementing demand-side measures and the time taken for behaviour change to occur." 154

Regardless of one's view on the timeliness or propriety of government intervention in meat consumption, one thing is clear: the pressing need for education of all groups, including policymakers, educators, government officials, and the public. ${ }^{155}$ The pervasive lack of knowledge about the connections between diet and climate change is arguably the paramount impediment to chang-

149. Dagevos \& Voordouw, supra note 147, at 66 (offering the further advice: "As a consequence, scholarly justification for more vigorous policy involvement may not be very helpful at the present time."). These writers apparently do not consider as "overreaching" the subsidies that most industrialized countries provide, which encourage greater meat consumption.

150. Id. (offering simple suggestions like "reducing the number of weekly meat meals" or eating low meat meals). They acknowledge that "the mitigation of meat consumption may not be a sufficient solution but it would be a major step forward if policy makers were to embrace cautious initiatives regarding the unsustainability of present meat-consumption patterns." Id.

151. Id. at 67 (citing the "four E's policy framework developed . . . in the UK").

152. Bailey et al., supra note 3, at 15 (citing Tara Garnett, Changing What We Eat: A Call for Research and Action on Widespread Adoption of Sustainable Healthy Eating, Food Climate Research Network (2014), available at http://www.fcrn.org.uk/sites/default/files/fcrn_wellcome_gfs_changing consumption_report_final.pdf; IPCC WORKING GRP. III, supra note 14).

153. See, e.g., Machovina et al., supra note 37, at 426; Eshel et al., supra note 48, at 11999 .

154. Cf. Pete Smith et al., How Much Land-Based Greenhouse Gas Mitigation Can Be Achieved Without Compromising Food Security and Environmental Goals? 19 Global Change Biology 2285, 2299 (2013).

155. See Bailey et al., supra note 3, at 2; Linnea I. Laestadius et al., Meat Consumption and Climate Change: The Role of Non-Governmental Organizations, 120 Climatic Change (2013) 25, 27 (citing the "continued need for public education campaigns with clear messages, particularly by environmental NGOs"). ing diets and, especially, reducing demand for beef. ${ }^{156} \mathrm{~A}$ recent multi-country, multilingual online survey, which was designed "specifically to explore public attitudes on the relationship between meat/dairy consumption and climate change," revealed "a major awareness gap about livestock's contribution to climate change."157 In fact, "[r] elative to other sectors, the awareness gap for livestock is particularly large. It also appears to be particularly inhibiting of change: for livestock, unawareness is significantly more likely to be associated with unwillingness to change behaviour than is the case for other sectors." 158 On the other hand, consumers "with a higher level of awareness were more likely to indicate willingness to reduce their meat and dairy consumption for climate objectives." 159 The researchers' conclusion: "Closing the awareness gap is therefore likely to be an important precondition for behaviour change." 160

A further, critical need is leadership. Although governments have been unwilling thus far to explore policy options, developed nations should take the lead in facilitating essential dietary changes. ${ }^{161}$ Industrialized nations are the largest consumers of meat products ${ }^{162}$; they would benefit the most health-wise by adopting more sustainable diets. Their citizens have more options in terms of food variety and higher incomes, both of which will facilitate dietary changes. These nations also have greater means of deploying public education strategies. And as a simple matter of equity, they should ask their citizens to reduce consumption before expecting action by poorer countries. ${ }^{163}$

156. While much more is required, simply "providing additional point of purchase information through labeling" could help close the awareness gap. See Laestadius et al., supra note 155, at 27; Bailey et al., supra note 3, at 22; Harvard L. Sch. Food L. \& Pol'y Clinic, Good Laws, Good Food: Putting State Food Policy to Work for Our Communities (2012), at 61 ("Often the most realistic option for targeting consumer behavior to change eating habits is by providing more or better information, which most commonly takes the form of nutrition labeling."), www.markwinne. com/wp-content/uploads/2012/.../food-toolkit-2012.pdf; as could advertising, cf. Machovina et al., supra note 37, at 426 (describing success in China in reducing consumption of shark fin soup).

157. Bailey et al., supra note 3 , at 22 .

158. Id.; cf. Thornton, supra note 7, at 2864 ("Much evidence points to a serious disconnect between science and public perceptions.")

159. Bailey et al., supra note 3, at 2. But cf. Capper, supra note 85, at 127 (remarking, somewhat cryptically: "All beef production systems are potentially sustainable; yet the environmental impacts of differing systems should be communicated to consumers to allow a scientific basis for dietary choices."). (Judith Capper is an animal scientist.)

160. Bailey et al., supra note 3 , at 2 .

161. Cf. Colleen McCain Nelson, Obama Calls for U.S. to Show Leadership in Fighting Climate Change, Wall ST. J., Aug. 31, 2015 (quoting President Obama as saying: " $[\mathrm{A}] \mathrm{s}$ the leader of the world's largest economy and its second-largest emitter, ... the United States recognizes our role in creating this problem and we embrace our responsibility to help solve it."), available at http://www.wsj.com/articles/obama-calls-for-u-s-to-show-leadership-infighting-climate-change-1441074557.

162. See, e.g., Jennifer Rivers Cole \& Suzanne McCoskey, Does Global Meat Consumption Follow an Environmental Kuznets Curve?, 9 Sustainability: SCI., Prac. \& Pol'y (Summer 2013), at 26, http://sspp.proquest.com; McMichael et al., supra note 7, at 1258; Thornton \& Herrero, supra note 7, at 12.

163. Cf. Mekonnen \& Hoekstra, supra note 43, at 413 ("Policies should not affect the required increase in food security in less developed countries [and] the livelihood of the rural poor should [not] be put in danger through intensification of animal farming."). 
A clear display of national leadership would include review and reform of the subsidies provided to animal agriculture. ${ }^{164}$ Numerous researchers and commentators have identified government subsidies and incentives as an important cause of increasing beef production and its attendant health and environmental impacts. To "stop subsidising beef production and promoting beef consumption" was the first of four "policy imperatives" formulated by one study for mitigating these impacts. ${ }^{165}$ Subsidies generally hide or fail to account for the external costs of beef, ${ }^{166}$ the researchers argued, and for this reason are "not environmentally responsible." ${ }^{\prime 67}$ If the goal is to alter consumer preferences for beef, subsidy reform must be a "high priority." 168 The IPCC also has identified the elimination of subsidies as a mechanism for mitigating GHG emissions. ${ }^{169}$ At least one commentator has argued that U.S. animal agricultural subsidies violate five provisions of Article 4 of the UNFCCC. ${ }^{170}$

U.S. subsidies that merit attention for the foregoing reasons include (among many others) the four programs discussed above: Farm Bill subsidies to growers of livestock feed, the Beef Checkoff, EPA's methane reduction strategy, ${ }^{171}$ and public-land livestock grazing. The remainder of this part focuses on public-land grazing, and explains why ending the federal land-grazing program should be an early, prominent measure in U.S. efforts to address the problems caused by animal agriculture. Accompanied by a clear explanation of the reasons for the new policy, the act of ending public-land grazing would be a clear affirmation that animal agriculture policies must change to meet the exigencies of climate change.

\section{Ending I50 Years of Public-Land Grazing}

Over the past 30 years, many scientists, legal academics, economists, and other commentators have criticized public-land grazing, some scathingly; several have advocated ending this land use altogether. ${ }^{172}$ Their arguments

164. Ironically, while some would consider subsidizing new behaviors or products, such as vegetal meat substitutes, as interfering with personal dietary choices, the discussion above shows how current, often long-standing subsidies have significantly influenced consumer choices of other foods, including beef.

165. See McAlpine et al., supra note 57, at 21, 29.

166. See id. at 29 (giving examples). Their research was based on case studies in Brazil, Colombia, and Queensland, Australia. See id. at 21.

167. See id. at 29; $c f$. Norman Myers \& Jennifer Kent, Perverse Subsidies: How Tax Dollars Can Undercut the Environment and the EconoMY 3-4, 49-50 (2001).

168. See McAlpine et al., supra note 57, at 29.

169. See IPCC Summary for Policymakers, supra note 90, at 28 (noting, however: "While subsidies can affect emissions in many sectors, most of the recent literature has focused on subsidies for fossil fuels."), available at https:// www.ipcc.ch/pdf/assessment-report/ar5/wg3/ipcc_wg3_ar5_summary-forpolicymakers.pdf.

170. See Winebarger, supra note 95, at 1016-30.

171. The failure to regulate methane emissions from enteric fermentation in ruminants is a substantial subsidy to that industry.

172. See, e.g., Beschta et al., supra note 59; Jonathan L. Batchelor et al., Restoration of Riparian Areas Following the Removal of Cattle in the Northwestern Great Basin, 55 Envtl. Mgmt. 930 (2015); Ripple et al., supra note 2; Hughes, supra note 139; Donahue, supra note 138; Costs And ConseQUENCES, supra note 132; Thomas L. Fleischner, Ecological Costs of Livestock have been based primarily on the profound environmental impacts on landscapes, water resources, and ecological processes; on the use's minor economic importance; and on the law. ${ }^{173}$ Recent, dramatic pronouncements about the urgency of including livestock production in climate change mitigation policies provide a new impetus for ending grazing on public lands. In other words, existing, well-documented criticisms of public-land grazing, combined with an understanding of methane's critical role in climate change, make a persuasive cumulative case for ending public-land grazing and ought to produce a tipping point on this issue.

While production of cattle and sheep on federal public lands is small and makes a minor direct contribution to U.S. diets, ${ }^{174}$ this is an extensive grazing system, which produces greater methane emissions than other forms of production. ${ }^{175}$ Based on current understanding of the key role of atmospheric methane, these emissions cannot be considered insignificant. ${ }^{176}$ Federal grazing also affects a huge

Grazing in Western North America, 8 Conservation Biology 629 (1994); Edward Abbey, Even the Bad Guys Wear White Hats, Harper's (Jan. 1986), at 51; Reed F. Noss, Cows and Conservation Biology, 8 Conservation Biology 613 (1994); Thomas Michael Power, Lost Landscapes and Failed Economies (1996); George K. Wuerthner, Subdivisions Versus Agriculture, 8 Conservation Biology 905 (1994); George Wuerthner, Climate Change and Livestock Grazing, CounterPunch, Feb. 6, 2015, http://www.counterpunch.org/2015/02/06/climate-change-and-livestock-grazing/; LYNN Jacobs, Waste of the West: Public Lands Ranching (1991); Phillip L. Fradkin, The Eating of the West, 81 Audubon 94 (1979); Johanna Wald et al., How Not to Be Cowed: Livestock Grazing on the Public Lands: An Owner's Manual (Natural Res. Def. Coun. \& Southern Utah Wilderness Alliance 1991); Nancy \& Denzel Ferguson, Sacred Cows at the Public Trough (1983); cf. Robert H. Nelson, Economic Analysis in Public Rangeland Management, in Western Public Lands: Natural Resources Management in a Time of Declining Federalism 53 (John G. Francis \& Richard Ganzel eds., 1984); Reed F. Noss \& Allen Y. Cooperrider, Saving Nature's Legacy: Protecting and Restoring Biodiversity ch. 7 (1994); Michael Hudak, Western Turf Wars: The Politics of PubLic Lands Ranching (2007); Joseph M. Feller, The Western Wing of Kafka's Castle, High Country News, Mar. 12, 1991, at 9; Richard J. Hobbs \& Laura F. Huenneke, Disturbance, Diversity, and Invasion: Implications for Conservation, 6 Conservation Biology 324 (1992); Elizabeth L. Painter, Threats to the California Flora: Ungulate Grazers and Browsers, 42 MADROÑO 180 (1995)

173. See Donahue, supra note 138; Beschta et al., supra note 59.

174. This fact should make it easier for policymakers to resist the arguments of the U.S. meat industry and a few commentators that increased ruminant production is both necessary to meet global food demand and sustainable. See, e.g., Capper, supra note 85; Cesar S. Pinares-Patiño et al., Effects of Intensification of Pastoral Farming on Greenhouse Gas Emissions in New Zealand, 57 N.Z. VET. J., 252, 260 (2009), doi:10.1080/00480169.2009.58618 ("GHG mitigation under extensive farming systems is not presently possible. ... However, ... food production, especially from forages, has a higher priority than mitigation of GHG from agriculture. For this reason, an increase in efficiency of ruminant productivity is important . . ."), http:// dx.doi.org/10.1080/00480169.2009.58618. See also Bailey et al., supra note 3 , at $10-11$.

175. See supra notes 46-47 and accompanying text.

176. But see U.S. Dept. of the Interior, Bur. of Land Mgmt., Medford District Office, Ashland Resource Area, Revised Environmental Assessment for the Cove Creek Grazing Lease Renewal 12 (DOI-BLMOR-M060-2009-0014-EA), Revision 2 (Sept. 2011) of the previously revised environmental assessment (May 2010) (concluding that calculated total methane emissions on the allotment (168 metric tons of $\mathrm{CO}_{2}$-eq per year) were insignificant because they "represent[ed] $0.0001 \%$ of the annual U.S. methane emissions from livestock, and $0.000002 \%$ of the annual U.S. emissions of all greenhouse gases, and $0.0000007 \%$ of the global emissions of all greenhouse gases"), link at www.blm.gov/or/districts/.../revcoveckea. pdf. These calculations may satisfy the Council on Environmental Quality's 
area, and its negative effect on carbon sequestration in soils on those lands is potentially large. ${ }^{177}$ Discontinuing livestock grazing on public lands also holds huge potential for promoting adaptation of public land resources to climate change. ${ }^{178}$ Ending this program would thus promote complementary adaptation and mitigation policies. For all these reasons, U.S. climate change policy should account for public-land grazing.

The general wisdom is that climate mitigation strategies are more likely to succeed if they produce cobenefits, or if they engage or complement other factors (for example, health) that motivate people. ${ }^{179}$ Thus, for example, the Obama Administration declared that reducing methane emissions "can deliver multiple benefits," namely, economic benefits, climate change benefits, public health, and safety. ${ }^{180}$ Similarly, reducing meat and dairy demand, especially in high-consuming countries, would "yield significant environmental and societal cobenefits for health, global food security, water security and biodiversity." ${ }^{181}$ Likewise, ending public-land grazing might contribute, if only modestly, to reducing demand for meat and thus promoting better health. But it would yield other, significant co-benefits, including climate change mitigation and adaptation, improved environmental quality, enhanced recreation opportunities, saved tax dollars, and more equitable treatment of livestock producers. Linking these benefits would help the government make its case to the public. ${ }^{182}$

In 2006, the FAO recognized the degraded condition of public rangelands in the western United States, as well as their "small contribution . . . to overall live-

(CEQ's) revised draft guidance for federal agencies on when and how to consider the effects of GHG emissions and climate change in accordance with the National Environmental Policy Act and the CEQ Regulations. See CEQ, Revised Draft Guidance for Greenhouse Gas Emissions and Climate Change Impacts (Dec. 18, 2014), at https://www.whitehouse. gov/administration/eop/ceq/initiatives/nepa/ghg-guidance. Standing alone, however, they are relatively meaningless.

177. See Beschta et al., supra note 59, at 481-82, 485. As these researchers explained:

While our findings are largely focused on adaptation strategies for western landscapes, reducing ungulate impacts and restoring degraded plant and soil systems may also assist in mitigating any ongoing or future changes in regional energy and carbon cycles that contribute to global climate change. Simply removing livestock can increase soil carbon sequestration since grasslands with the greatest potential for increasing soil carbon storage are those that have been depleted in the past by poor management (Wu et al. 2008, citing Jones \& Donnelly 2004). Riparian area restoration can also enhance carbon sequestration (Flynn et al. 2009).

Id. at 485; see also Ripple et al. supra note 2, at 2, 3; Wuerthner, CounterPunch, supra note 172.

178. See generally Beschta et al., supra note 59; see also Hughes, supra note 139; Ripple et al., supra note 2; Batchelor et al., supra note 172.

179. Bailey et al., supra note 3 , at 22-23.

180. STRATEgY, supra note 116, at 1-2.

181. Bailey et al., supra note 3, at 22, 14; see also Axel Michaelowa \& Björn Dransfeld, Greenhouse Gas Benefits of Fighting Obesity, 66 Ecological Econ. 298 (2008). William Ripple et al. concluded: "Reductions in ruminant numbers and meat production would benefit global food security, human health, and environmental conservation." Ripple et al., supra note 2 , at 2 .

182. Cf. Meckling et al., supra note 24, at 1171 ("Linking issues allows for greater leverage in policy-making."). stock supply." ${ }^{183}$ More valuable uses of these lands, the agency suggested, would be to help support the "growing demands for other uses such as recreation [and other] environmental services." Converting the lands "back to their original state" - which the FAO believed was a "real possibility"-would promote the ability of the lands to support these services. ${ }^{184}$ This recommendation presaged the conclusion of a 2012 study regarding the need for, and the means of, restoring the western public lands' capability to provide ecosystem services. ${ }^{185}$ The reviewers exhorted federal and state land management agencies to "reduce significant ungulate [primarily livestock] impacts in order to facilitate ecosystem recovery and improve resiliency." Such actions, they argued, "represent the most effective and extensive means for helping maintain or improve the ecological integrity of western landscapes and for the continued provision of valuable ecosystem services during a changing climate." 186

Given the awareness gap regarding animal agriculture and climate change, ${ }^{187}$ the federal government should clearly inform the public of all co-benefits of removing livestock from public lands. The decision should state explicitly that it is motivated in part by recent determinations that dramatic reductions in agricultural methane emissions are essential to slow escalating global temperatures and increase the chance that disastrous climaterelated tipping points can be avoided. Combined with what is already known about the deleterious effects of livestock, this scientific understanding greatly strengthens the case for removing livestock from public lands.

Ironically, as intractable as public-land grazing politics has proved to be, the law poses no insurmountable obstacle to removing livestock from the public's lands. ${ }^{188}$ As noted above, a grazing permit is not a property right ${ }^{189}$; it can be cancelled with two years' notice (less, in an emergency) "to devote the lands . . . to another public purpose. ${ }^{190}$ Permits can be suspended or canceled "for any violation of a grazing regulation or of any term or condition of such grazing permit." ${ }^{191}$ The public-land laws identify

183. STEINFeld ET AL., supra note 1, at 261 (singling out the western United States and western Australia as examples of the "widespread degradation of state-owned land leased out to individual farmers").

184. See id.

185. See Beschta et al., supra note 59, passim.

186. Id. at 487.

187. See supra notes $157-60$ and accompanying text.

188. See Beschta et al., supra note 59, at 482-83 (providing a brief summary of relevant law); see also Donahue, supra note 144, at 763 n.305; Donahue, supra note 138, at 203-18. Moreover, grazing is causing both "unnecessary" and "undue degradation" of the public lands, which is prohibited by 43 U.S.C. $\$ 1732(\mathrm{~b})$.

189. See 43 U.S.C. $\$ \$ 315 b, 1752(j)$.

190. See 43 U.S.C. $\$ 1752$ (g); $\$ 1903$ (b) (referring to a secretarial decision that grazing uses should be "discontinued (either temporarily or permanently) . . on certain lands”). See also 43 C.F.R. $\$ 4130.2$ (BLM rules concerning grazing permits or leases); 43 C.F.R. Subpt. 4180 (Fundamentals of Rangeland Health and Standards and Guidelines for Grazing Administration). Other measures available to land managers include suspending permits or modifying the terms and conditions to which they are subject. See 43 U.S.C. $\$ 1752(\mathrm{a})-(\mathrm{b})$.

191. 43 U.S.C. $\$ 1752(a)$. 
grazing as a permissible "multiple use" of public lands. ${ }^{192}$ The laws do not mandate, however, that livestock grazing be allowed on any particular public lands, much less on the vast majority of them. ${ }^{193}$ Reasonable interpretation of BLM's and USFS' multiple-use, sustained-yield mandates supports this conclusion. As I have written elsewhere:

If the laws governing public lands and resources were applied honestly and sensibly, our management prescriptions would change. We would manage BLM lands and national forests sustainably, in the national interest, to prevent impairment of their productivity. Giving due regard to the relative value and scarcity of resources, we would accord priority to protecting riparian areas and other native communities and species, recognizing that they "cannot be duplicated elsewhere.". . We would end public-land grazing because using these lands to grow a commodity that can be produced anywhere is plainly not "the most judicious use."194

Additional support is found in Congress' declaration that "it is the policy of the United States that the public lands be managed in a manner which recognizes the Nation's need for domestic sources of . . . food . . . and fiber from the public lands." 195 There can be no legitimate argument that Americans "need" the animal products attributable to public land forage. ${ }^{196}$ Instead, the opposite is true: atmospheric scientists, nutritionists, and ecologists, respectively, urge that livestock methane emissions be cut, that Americans eat less red meat, and that ungulate populations be reduced on federal public lands.

Thus, although congressional action to discontinue grazing would be desirable, it is not required. ${ }^{197}$ Without new legislation, the agencies could reduce livestock numbers by proceeding permit-by-permit and/or revising land use plans.

All of this is not to say that effectuating this policy change would be easy. Recently, in an attempt to forestall the need to protect the greater sage-grouse under the Endangered Species Act (ESA), ${ }^{198}$ BLM and USFS

192. See, e.g., 43 U.S.C. $\$ 1702$ (c), (h); 16 U.S.C. $\$ 528$.

193. In fact, the Federal Land Policy and Management Act (FLPMA) explicitly addresses the Interior Secretary's authority to render a "management decision or action ... that excludes (that is, totally eliminates) one or more of the principal or major uses [including grazing] for two or more years with respect to a tract of land of one hundred thousand acres or more." See 43 U.S.C. $\$ 1712(\mathrm{e})$.

194. Debra L. Donahue, Trampling the Public Trust, 37 B.C. Envtl. Afrs. L. Rev. 257, 310-11 (2010) (citing 16 U.S.C. \$\$528-529, 531, 1601(d)(1), 1604(b), (e), (g), 1607; 43 U.S.C. $\$ \$ 1701(\mathrm{a})(11), 1702(\mathrm{c}),(\mathrm{h}), 1711(\mathrm{a})$, 1712 (c) (3)). These are only a few of the relevant statutes.

195. FLPMA, 43 U.S.C. $\$ 1701$ (a)(12) (emphasis added).

196. Elsewhere, I offered an alternative argument, that "public lands can provide 'food' and 'habitat' for domestic livestock even if the animals never set foot on public land. For example, public lands produce water, support pollinators, and provide pest control - all of which serve livestock production on private lands." Debra L. Donahue, Federal Rangeland Policy: Perverting Law and Jeopardizing Ecosystem Services, 22 J. Land Use \& EnvtL. L. 299, 323 \& n.158 (2007).

197. Cf. John D. Leshy \& Molly S. McUsic, Where's the Beef? Facilitating Voluntary Retirement of Federal Lands From Livestock Grazing, 17 N.Y.U. ENVTL. L.J. 368 (2008).

198. 16 U.S.C. $\$ 1534$. issued "amendments or revisions to 98 land management plans governing over half of the occupied range" of the grouse. ${ }^{199}$ While all of these changes addressed the habitat impacts of livestock grazing, none "substantively changed livestock land use allocations." 200 The agencies did commit to "consider," at "the time a permittee or lessee voluntarily relinquishes a permit or lease," "whether the public lands where that permitted use was authorized should remain available for livestock grazing or be used for other resource management objectives." 201 This approach to "managing" the impacts of livestock grazing reflects federal reluctance to curtail public-land ranchers' privileges, which largely explains why, despite the indisputable environmental effects of grazing, the authority outlined above has seldom been exercised.

Another revealing example involves a BLM initiative known as "rapid ecoregional assessments," a tool for describing and evaluating the influences on western landscapes of significant "environmental change agents." The agency identified four: "climate change, wildfire, invasive species, and development." ${ }^{202}$ It declined explicitly to include livestock grazing as a "change agent," even though livestock's impacts are more widespread than any of the listed factors, and despite the fact that grazing contributes to or aggravates the first three. BLM defended its decision, citing "anxiety from 'stakeholders,' fear of litigation and . . lack of available data on grazing impacts." 203

199. See Endangered and Threatened Wildlife and Plants; 12-Month Finding on a Petition to List Greater Sage-Grouse (Centrocercus urophasianus) as an Endangered or Threatened Species, 89 Fed. Reg. 59858, 59874 (proposed Oct. 2, 2015) (to be codified in 50 C.F.R. Part 17). Greater sage-grouse occur in 11 western states. See id. at 59865 (fig. 1).

200. See id. at 59877.

The Federal Plans have not substantively changed livestock land use allocations; however, the BLM and USFS have committed to implementation of vegetative standards and habitat objectives specifically for sage-grouse based on local ecological conditions and prioritization of monitoring in [Priority Habitat Management Areas] to determine if they are meeting sage-grouse habitat objectives consistent with site-specific guidelines or ecological site descriptions.

Id. Specifically, the agencies have committed to implementing a number of measures related to monitoring, prioritizing field checks in certain areas to determine compliance with new conditions and to base permit renewals on site conditions and health standards, enabling adjustments in grazing without NEPA compliance, etc.

201. Id. (emphasis added).

202. See BLM, Rapid Ecoregional Assessments, http://www.blm.gov/wo/st/en/ prog/more/Landscape_Approach/reas.html (last visited Oct. 23, 2015).

203. See PEER, Grazing Punted From Federal Study of Land Changes in West: Scientists Told to Not Consider Grazing Due to Fear of Lawsuits and Data Gaps, Nov. 30, 2011, http://www.peer.org/news/news-releases/2011/11/30/ grazing-punted-from-federal-study-of-land-changes-in-west/ (last visited Oct. 23, 2015). Agency scientists who participated in the process objected, observing: "We will be laughed out of the room if we don't use grazing. If you have the other range of disturbances, you have to include grazing." See id. The notion that the agency could "lack . . . available data on grazing impacts" is also laughable, given that BLM has had mandates to manage grazing since its inception in 1946, first under the Taylor Grazing Act, 43 U.S.C. $\$ \$ 315-315 b$, and then under FLPMA, 43 U.S.C. $\$ \$ 1732,1752$, and the 1978 Public Rangelands Improvement Act, 43 U.S.C. $\$ \$ 1901-1903$. 
Implementing the proposal to end or drastically curtail public-land grazing will depend broadly on education and leadership. ${ }^{204}$ The following elements are crucial:

- recognition by USFS and BLM that the law does not direct them to protect ranchers' preferred lifestyle, ${ }^{205}$ paired with a better understanding of their legal authority ${ }^{206}$;

- stronger enforcement of agency obligations to protect public lands and prevent damaging or unsustainable use by livestock ${ }^{207}$;

- better public information regarding land management agency actions and responsibilities ${ }^{208}$;

204. Cf. supra notes $155-65$ and accompanying text.

205. Cf. Timothy Egan, Wingtip "Cowboys" in Last Stand to Hold on to Low Grazing Fees, N.Y. Times, Oct. 29, 1993, at http://www.nytimes.com/1993/10/29/ business/wingtip-cowboys-in-last-stand-to-hold-on-to-low-grazing-fees. html (reporting that Sen. Alan Simpson (R-Wyo.) justified a week-long filibuster to prevent an increase in federal grazing fees, thereby holding up the $\$ 12$ billion DOI budget, as "defending a Western life style").

206. See generally Donahue, supra note 146; Donahue, supra note 196, at 308 \& n.62, 329 (reporting BLM's view that its authority to limit grazing is very limited because FLPMA allows or requires grazing); see also id. at 344-45. BLM regulations do state that "provid[ing] for the sustainability of [1] the western livestock industry and [2] communities that are dependent upon productive, healthy public rangelands" are objectives of grazing administration. See 43 C.F.R. $\$ 4100.0-2$. The first objective, however, cannot be squared with the facts or the governing statutes. The "western livestock industry" does not depend on public lands. See Donahue, supra note 146, at 730 ("Seventy percent of western cattle producers own all the land on which they operate; fewer than 23,000 livestock producers (about two percent of one million nationwide) possess federal grazing permits."); see also supra note 141 and accompanying text. The Taylor Grazing Act directed the Secretary to "do any and all things necessary" to "stop injury to the public grazing lands by preventing overgrazing and soil deterioration, to provide for their orderly use, improvement, and development, [and] to stabilize the livestock industry dependent upon the public range." 48 Stat. 1269 (1934). But the "Act treats stabilizing the livestock industry as a secondary goal." Public Lands Coun. v. Babbitt, 167 F.3d 1287, 1299 n.5 (10th Cir. 2000), aff d on other grounds, 529 U.S. 728, 30 ELR 20566 (2000). As for the rule's second objective, people in western communities are far more dependent on "healthy public rangelands" for ecosystem goods and services other than beef production. See generally Donahue, supra note 196, Part III; 43 U.S.C. $\$ 1901(\mathrm{a})(1)$ (recognizing that rangelands produce "wildlife habitat, recreation, forage, and water and soil conservation benefits").

207. The agencies cannot claim ignorance of the ongoing impacts of livestock grazing. In 1978, the Assistant Secretary of the Interior, in testimony before Congress, stated: "Rangeland deterioration is . . . inconsistent with the sustained yield principle of public resource management legislated by FLPMA." See Donahue, supra note 196, at 321 \& n.140 (quoting Guy Martin). In 1994, the federal government reported that "[w]atershed and water quality conditions would improve to their maximum potential" if livestock were removed from public lands. RANGELAND REForm '94, supra note 140. (USDA contributed to this analysis.) Yet, neither BLM nor USFS has acted on what it knows. At a minimum, the agencies should strictly enforce rangeland health standards and guidelines, and order removal of livestock before exceedances of specified site conditions are imminent, especially during drought conditions. Cf. generally 43 C.F.R. subpt. 4100.

208. Recall that the "awareness gap" with respect to livestock is "particularly inhibiting of change" in climate policy. See supra note 158 and accompanying text. The awareness gap regarding public-land grazing issues is huge. This became glaringly apparent during the media coverage of rancher Cliven Bundy's disputes with BLM in 2014. (A Google search for "Cliven Bundy" produced about 392,000 results.) See, e.g., Gail Collins, Of Fox and the Cattle, N.Y. Times, Apr, 26, 2014, at A21; Phil Taylor, Bundy Owes U.S. More Than All Other Ranchers Combined, GreEnwire, June 4, 2014; Jaime Fuller, Everything You Need to Know About the Long Fight Between Cliven Bundy and the Federal Government, Wash. Post, last post, Apr., 14, 2014 (providing a chronology), http://www.washingtonpost.com/blogs/ the-fix/wp/2014/04/15/everything-you-need-to-know-about-the-long-
- coordinated support by environmental organizations ${ }^{209}$; and, above all,

- the political will to challenge the status quo. ${ }^{210}$

Situating public-land grazing in the context of climate change would elevate its profile among the public and might help to garner the attention of both the public and policymakers who currently have little knowledge of or interest in public-land grazing. Substantial progress is being made globally on energy-based efforts to mitigate climate change. ${ }^{211}$ Given this momentum, perhaps it is not too much to hope that attention to the role of ruminant meat production reaches a tipping point before the climate and western landscapes do.

\section{Conclusion}

Removing livestock from public lands would generate myriad co-benefits over the short and long term and over a vast area of the West. First, eliminating this extensive grazing by ruminants would cut methane emissions, with attendant benefits for climate mitigation. If the loss of federal grazing privileges induced permit holders to give up ranching, the emissions benefits would expand accordingly. Second, removing livestock from public lands is consistent with federal nutrition policy, particularly the recommendation to eat less red meat; thus, health benefits provide an additional leverage point. Third, removing livestock would

fight-between-cliven-bundy-and-the-federal-government/; Travis Bruner \& Greta Anderson, Cliven Bundy Steals From America: The Scary Return to a West Where Guns—Not Law-Rule, SALON, Apr. 18, 2014. While Bundy's egregious behavior is far from typical of grazing permittees, many people did not understand that, and BLM did little to dispel misconceptions. At the same time, BLM's unwillingness or inability — even when armed with a court order-to enforce payment of Bundy's astonishing fees and fines or removal of his trespassing cattle left many people wondering why BLM allowed Bundy's illegal conduct to continue for years, and whether he would ever be held to account. (Why local law enforcement authorities allowed tensions to escalate to an armed standoff, whether Bundy's self-appointed militia suffered any legal consequences, and if not, why not, are separate questions that deserve answers.) While the Bundy saga is an outlier, it does highlight the critical need to educate the public. Unfortunately, it is also potent evidence of the difficulties that attempts to remove livestock from public lands will face, and why — at least for now—such attempts seem unlikely. See infra note 210 and accompanying text.

209. Livestock grazing issues, like meat production, are a priority for very few environmental organizations. See Cowspiracy: The Sustainability Secret (A.U.M. Films 2014), at www.cowspiracy.com; cf. generally Laestadius et al., supra note 156; id. at 36 ("The voice of environmental NGOs, now largely absent, would be particularly important in lending legitimacy to [policy efforts linking climate and diet]."); accord Myers, supra note 92, at 39. As long as groups perceive other problems as more pressing, those preconceived views, along with limited resources, will frustrate the attempts of a few groups and individuals to achieve reform. Furthermore, this general disinterest is a disincentive to agency officials who might otherwise be inclined to take stronger measures to prevent continuing land degradation caused by livestock (such as those recommended by Beschta et al., supra note 59, at 487-88).

210. "Political courage" has long been "the range resource in the shortest supply." George Cameron Coggins, The Law of Public Rangeland Management V: Prescriptions for Reform, 14 ENVTL. L. 497 (1984).

211. See Jonathan Chait, This Is the Year Humans Finally Got Serious About Saving Themselves From Themselves, N.Y. MaG., Sept. 7, 2015, at http:// nymag.com/daily/intelligencer/2015/09/sunniest-climate-change-story-ever-read.html (describing the progress in the past year and concluding: "Eventually the world will wean itself almost completely off carbonbased energy."). 
eliminate the cause of much of the degraded environmental conditions on public lands and waters, thereby enabling improvement or even recovery. ${ }^{212}$ And finally, this policy initiative makes fiscal sense. The passive approach to restoration is relatively inexpensive, ${ }^{213}$ and ending this federal program would save taxpayer dollars.
Ending public-land livestock grazing would signal the federal government's choice to put Americans' health and the livability of planet earth ahead of narrow economic interests, political cronyism, and hollow traditions.

212. See, e.g., Beschta et al., supra note 59; Batchelor et al., supra note 172; Ripple et al., supra note 2.

213. See, e.g., Beschta et al., supra note 59, at 483 ("[P]assive restoration [approaches], are generally the most ecologically effective and economically efficient for recovering altered ecosystems because they address the root causes of degradation and allow natural recovery processes to operate."); Batchelor et al., supra note 172, at 941 ("Simply removing cattle from areas may be all that is required to restore many degraded riparian areas in the American West."). 